\title{
Balkan Savaşları Esnasında Alman Salib-i Ahmer (Kızılhaç) Cemiyeti’nin İstanbul ve Edirne'de Yürüttüğü Sağlık Çalışmaları
}

\author{
Muttalip Şimşek* $^{*}$
}

\begin{abstract}
$\ddot{O}_{z}$
1864'te imzalanan Cenevre Sözleşmesi'yle birlikte cephelerde askerî sağlık hizmetlerinin mükemmel bir şekilde yapılması anlayışı gelişmeye başlamışve Avrupa'nın farklı ülkelerinde birbiri ardına Kızılhaç cemiyetleri kurulmuştu. Bunlardan birisi de Alman Kızılhaç teşkilatıdır ve bu kuruluş sadece Almanya'da değil dünyanın farklı bölgelerinde meydana gelen savaşlarda din ve milliyet ayrımı yapmaksızın cephelerde sağlık çalışması yürütmüştür. Alman Kızılhaçı özellikle Trablusgarp Savaşı (191112), Balkan Savaşları (1912-13) ve Birinci Dünya Savaşı (1914-18) esnasında doktor, hemşire ve hastabakıcılardan oluşan ekiplerle Osmanlı cephelerinde hizmet etmiştir.

Bu çalışmada, öncelikle Alman Salib-i Ahmer Cemiyeti’nin Balkan Savaşları'nın başlamasıyla birlikte hem Osmanlı Devleti'ne, hem de Balkan ülkelerine sağlık ekibi göndermek için nasıl bir seferberlik yürüttüğü açıklanacaktır. Daha sonra, sağlık ekiplerinin Almanya'daki üniversitelerde görev yapan tecrübeli doktorların idaresi altında uzman sağlık personeliyle birlikte İstanbul ve Edirne'de yürüttükleri çalışmalar detaylı bir şekilde değerlendirilecektir. Bunların yanında, Türk askerinin cephede oldukça zor şartlarda savaşmasına bağlı olarak ortaya çıkan kangren vakaları ve diğer ağır hastalıklara karşı verdiği mücadele ve Alman sağlık ekibinin Hilal-i Ahmer Cemiyeti'yle birlikte bu alanda yürütmeye çalıştığı hizmetler ortaya konacaktır. Ayrıca, Alman sağlık ekiplerinin kayıtları ışı̆̆ında, tedavi edilen hastalara dair sayısal bilgiler verilerek, salgın hastalıklarla mücadele ve Ayastefanos (Yeşilköy) Karantina Merkezi’nin çalışmaları da burada detaylı bir şekilde değerlendirilecektir.
\end{abstract}

Anahtar Kelimeler: Osmanlı Devleti, Balkan Savaşları, Alman Salib-i Ahmer Cemiyeti, İstanbul, Edirne

* Dr., Milli Eğitim Bakanlığı, Konya/TÜRKIYE, mutsimsek@gmail.com ORCID: 0000-0003-1184-2345

DOI: ??????????

Makale Gönderim Tarihi: 26.12.2019 - Makale Kabul Tarihi: 11.08.2020

Belleten, Nisan 2021, Cilt: 85/Sayı: 302; 155-191 


\title{
Healthcare Activities of the German Red Cross in Istanbul and Edirne during the Balkan Wars
}

\begin{abstract}
Together with the Geneva Convention signed in 1864 the understanding of perfect military healthcare services on the fronts began to develop and Red Cross Societies were established one after another in different countries of Europe. One of them is the German Red Cross Societies and this organization carried out health activities on the fronts without distinction between religion and nationality in wars that took place not only in Germany but also in different parts of the world. The German Red Cross served on the Ottoman fronts, especially during the Tripoli War (1911-12), the Balkan Wars (1912-13) and the First World War (1914-18), together with teams of doctors, nurses and caregivers.

In this study, firstly with the beginning of the Balkan Wars, it will be explained how the German Red Cross carried out a campaign to send healthcare teams both to the Ottoman Empire and to the Balkan countries. Afterwards, the activities put into practice by the healthcare teams in Istanbul and Edirne with expert health professionals under the supervision of experienced doctors working in universities of Germany will be evaluated in detail. In addition to this, the fight against gangrene cases and other serious diseases caused by the difficult conditions in which the Turkish soldiers were fighting on the front and the services that the German health professionals tried to carry out in this field together with the Red Crescent Society will be revealed. Additionally, in the light of the records written by the German medical teams numerical information about the treated patients will be given. Finally, fighting against the epidemics and the activities of the San Stefanos (Yeşilköy) Quarantine Center will also be discussed in detail here.
\end{abstract}

Keywords: The Ottoman Empire, The Balkan Wars, The German Red Cross, Istanbul, Edirne

\section{Giriş}

"On yıllık savaş dönemi" olarak tabir edilen ve Trablusgarp ile başlayıp Balkan Savaşlarıyla devam eden, Birinci Dünya Savaşı ve sonrasında verilen Milli Mücadele ile son bulan bu süreç Türk Tarihi açısından zorlu bir dönemi ifade etmektedir. Bu savaşların her biri ayrı bir kırılma noktasına sahip olmasına karşın Balkan Savaşları, asırlardır hâkimiyetimiz altında bulunan toprakların kısa bir süre 
içerisinde elimizden çıması ile asker ve sivil binlerce insanın hayatını kaybetmesi gibi pek çok olumsuz neticeyi de beraberinde getirmişti. Bilindiği gibi, Osmanlı Devleti Trablusgarp'ta İtalya'ya karşı mücadele ederken Balkan devletleri arasında hareketlenmeler görülmüş ve Rusya'nın da teşvikiyle bölgede Osmanlı'ya karşı ittifak görüşmeleri başlamıştı. Haddizatında bu, 93 Harbi (1877-78) neticesinde imzalanan Ayastefanos (daha sonra Berlin) Antlaşması'yla Türkleri Rumeli'den atma projesinin nihaî safhasını oluşturuyordu ${ }^{1}$.

Aslında II. Abdülhamid'in Balkanlar'da takip ettiği siyaset nedeniyle bölgede bir ittifakın oluşması uzun yıllar engellenmişti. Her şeyden önce Bulgar Kilisesi'nin Rum Ortodoks Kilisesi’nden ayrıldığı tarihten beri Makedonya'daki birçok kilise ve mektebin hangi kiliseye mensup olduğuyla ilgili bir "kiliseler meselesi" bulunuyordu. Meşrutiyet idaresinin 3 Temmuz 1910 tarihinde Kiliseler ve Mektepler Kanunu'nu çıkartarak Makedonya'daki Bulgar, Sırp ve Yunan azınlıkları arasında hakemlik yapması bölgedeki ihtilafın en büyüğünü ortadan kaldırmıştı ${ }^{2}$. Diğer taraftan, Rusya'nın ön ayak olmasıyla Balkanlarda bir ittifak rüzgârı esmeye başladığı halde Osmanlı Hükûmeti bu girişimlere karşı bir tedbir almak yerine Rumeli'de bulunan 120 tabur askeri terhis etmişti. Üstelik Fransa'nın ve o dönem Osmanlı'nın Atina Maslahatgüzarı Galip Kemalî Bey'in Balkanlarda ittifak kurulacağına yönelik uyarıda bulunmalarına rağmen hükûmet, Surbistan'ın Avrupa'dan getirttiği ve savaş başlayınca Osmanlı askerlerine karşı kullanacağı son model ağır topları Selanik Limanı'ndan demiryoluyla Belgrad'a nakline de müsaade etmişti ${ }^{3}$.

Rusya'nın ön ayak olmasıyla Balkan devletleri arasında ittifak görüşmeleri başlamış ve neticede bu ittifak 1912 yılının Ekim ayına kadar büyük oranda şekillenmişti ${ }^{4}$.

1 Berlin Antlaşması (1878) Rumeli topraklarının büyük bir kısmını Osmanlı'dan koparmıştı ancak, terkedilen bu topraklar üzerindeki taksim mücadelesi Balkan devletleri arasında aralıksı devam etmiştir. II. Meşrutiyet'in ilanından sonra Avusturya Berlin Antlaşması'ndan beri işgal ettiği BosnaHersek'i ilhak etmiş (3 Ekim), Osmanl’ya bağlı muhtar Bulgaristan Prensliği de bağımsızlı̆̆ını ilan etmişti (5 Ekim). Bu olayın hemen ertesi günü ise Yunanistan Girit’i topraklarına kattığını açıklamıştı. Dolayısıyla Balkanlar'daki bu son durum yeni gelişmelerin önünü açacak ve ittifak görüşmeleri neticesinde Balkan Savaşları'nın başlamasına giden süreci başlatacaktır. Yılmaz Öztuna, Büyük Türkiye Tarihi, C 7, Ötüken Neşriyat, İstanbul 1978, s. 263-278.

2 Cevdet Küçük, "Balkan Savaşı", TDV İslam Ansiklopedisi, C 5, İstanbul 1992, s. 23.

3 Ali Fuat Türkgeldi, Görüp İsittiklerim, TTK Basımevi, Ankara 2010, s. 57-58.

4 Aram Andonyan, Balkan Harbi Tarihi, çev. Zaven Biberyan, Sander Yayınları, İstanbul 1975, s. 192 vd.; Öztuna, age., s. 264. Balkan ittifakının oluşmasında Rusya'nın etkisi için bk. Leo Trotzki, Die Balkankriege 1912-13, Übersetzt (Aus dem Russisch): Hannelore Georgi und Harald Schbärth, Arbeiterpresse Verlag, Essen 1995, s. 12. 
Balkanlar'da ittifak planları yapılırken Osmanlı Devleti iç işleriyle uğraştı̆̆ için bu gelişmelerden haberdar olamadı. Devletin hâlihazırda İtalya ile harpte olması, Rumeli'deki iyi durumda olan 120 taburun terhis edilmesi ve bunların yanında ordu içerisindeki subayların hizipleşmeleri (İttihatçı ve Halâskâr) nedeniyle Türk ordusu seferberliğini çok geç yapabildi. Osmanlı kuvvetleri sayıca üstün olmasına karşın Batı'dan satın alınan son model silahlarla teçhiz edilmiş ve seferberliğini muntazam bir şekilde tamamlamış olan Balkan devletlerine ${ }^{5}$ karşı mücadele edecek durumda değildi ${ }^{6}$.

Arnavut isyancıların 3 Ekim 1912 tarihinde Karadağ’a sığınmaları üzerine Osmanlı Devleti bölgeye asker sevk etti. Bunun üzerine Bulgaristan, Surbistan, Yunanistan ve Karadağ hükûmetleri aynı gün Bâb-1 Âli'ye bir nota vererek üç gün içinde eski Sırbistan, Makedonya, Arnavutluk ve Girit'e muhtariyet verilmesini istediler. Verilen süre bitince isteklerini tekrarlayarak Osmanlı'ya yeniden üç günlük süre tanıyan Balkan ülkeleri Batılı devletlere de ortak nota vererek istekleri kabul edilmediği takdirde silah ile Osmanlı Devleti'ne kabul ettireceklerini bildirdiler. Neticede 8 Ekim 1912'de Karadağ'ın Osmanlı Devleti'ne tek taraflı savaş ilan etmesiyle Balkan Savaşları'nın ilk safhası başlamış oldu. Bunu, Sırbistan ve Bulgaristan'ın 14 Ekim'de, Yunanistan'ın da aynı günlerde Osmanlı'ya savaş ilan etmesi takip etti ve cephelerde silahlar ateşlenmeye başladr ${ }^{7}$.

Seferberliğin gecikmesi, ordu içerisinde görüş ayrılıkları ve terhis edilen askerin yeniden orduya celbi meselesi gibi eksikliklere rağmen savaş başlamıştı ve bu andan itibaren yapılacak tek şey düşmana galip gelmek için milleti topyekûn bu mefkûre etrafinda seferber kılmaktı. Zira cephede düşmana karşı verilen askerî mücadele harbin mukadderatı açısından ne kadar mühimse, cephe gerisinde yaralı ve hasta askerlere verilen sağlık hizmeti de en az bu mücadele kadar önemliydi.

5 Diğer Balkan devletleriyle kıyaslandığında gerek asker sayısı, gerekse savaş teçhizatı açısından Karadağ biraz daha zayıf bir vaziyette idi. Richard C. Hall, Balkan Savaslarn 1912-1913, I. Dünya Savaşı'nın Provası, çev. M. Tanju Akad, Homer Kitabevi, İstanbul 2003, s. 73-74; Ragıb Rifkı, Balkan Hukûmetlerinin Teşkilât- Askeriyesi (Romanya, Bulgaristan, Sirbistan, Munanistan, Karadağ Ordularna Dair Yeni ve Son Malumatı Havidir), Şems Matbaası, Dersaadet H.1328/R.1330, s. 3-25.

6 Ali İhsan Sabis, Balkan Savaşı’nda Neden Bozguna Uğradık, Balkan Savaşı’nda Askerî Yenilgimizin Sebepleri, Alfa Yayınları, İstanbul 2012, s. 69. Bulgarlar'a esir düşen Türk askerlerinin dilinden Osmanlı subaylarının savaş esnasındaki tutumu ve yenilgideki payları ile ilgili bk. Lev Troçki, Balkan Savaşları, çev. Tansel Güney, Türkiye İş Bankası Kültür Yayınları, İstanbul 2019, s. 283-288.

7 Hall, age., s. 52-53.

Belleten, Nisan 2021, Cilt: 85/Sayı: 302; 155-191 


\section{Alman Salib-i Ahmer (Kızılhaç) Cemiyeti'nin İstanbul ve Edirne'de Yürüttüğü Sağlık Çalışmaları}

Osmanlı Devleti cephe gerisinde askere sağlanacak her türlü hizmet hususunda Kırım Harbi'nden beri belirli bir tecrübe kazanmıştı. Özellikle Osmanlı-Rus Savaşı (1877-78), Osmanlı-Yunan Savaşı (1897) ve Trablusgarp Savaşı (191112)'nda cephedeki yaralı ve hasta askerlerin tedavisi ile ilgili Osmanlı Hilal-i Ahmer Cemiyeti önemli çalışmalar yürütmüştü. Balkanlarda savaş rüzgârı esmeye başlayınca Hilal-i Ahmer Cemiyeti Başkanı Hüseyin Hilmi Paşa'nın çağrısı ile Cemiyet Yönetim Kurulu sık sık toplanarak olası savaş durumunda nasıl bir çalışma yürütüleceği ile ilgili görüşmeler yapmaya başladı. Bu süreçte, Cemiyet sadece yaralı askerlere değil, Balkanlardan gelecek göçmenlere de her türlü yardımı yapmayı planlıyordu. Bu çalışmalarda İstanbul başta olmak üzere Edirne, Üsküp, Lüleburgaz, İşkodra, Yanya, Manastır ve Alasonya'da askerî hastaneler kurulmasına karar verilmiş ancak, maddî yetersizlikler ve savaşın ilerleyen günlerinde bu şehirlerden bir kısmının düşman eline geçmesi nedeniyle çalışmalar birkaç şehir ile sınırlı kalmıştı. Savaş başlar başlamaz Hilal-i Ahmer Cemiyeti, İstanbul'daki mevcut hastaneleri malzeme ve sağlık ekibi noktasında takviye ettiği gibi sadece Ekim ayı içerisinde payitahtta sekiz yeni askerî hastane kurarak cepheden gelecek yaralı askerlerin tedavisini yapabileceği düzeni oluşturmaya çalışmışı ${ }^{8}$.

Hilal-i Ahmer Cemiyeti Trablusgarp Savaşı başladığında bölgeye sağlık ekibi göndermiş ve bölgenin farklı yerlerinde hastane ve poliklinikler oluşturarak çalışmalar yürütmüş; aynı zamanda uluslararası Kızllay/Kızılhaç cemiyetlerine de yardım çağrısı yapmıştı ${ }^{9}$. Ancak Balkan Savaşı başlarında cemiyet, böyle bir çağrı yapmadığı halde başta Mısır ve Hindistan Hilal-i Ahmer Cemiyetleri olmak üzere Romanya, İngiltere, Almanya, Avusturya-Macaristan, Belçika, İsveç, Amerika, Flemenk (Hollanda), Fransa ve Rusya Kızılhaç cemiyetleri gerek malzeme, gerekse sağlık heyetleri göndermek suretiyle Osmanlı Hilal-i Ahmer Cemiyeti’ne destek vermeye çalışmışlard $1^{10}$.

8 Seçil Karal Akgün - Murat Uluğtekin, Hilal-i Ahmer'den Kizılay'a, Ankara 2002, s. 100-108.

9 Muttalip Şimşek, “Trablusgarp Savaşı'nda Alman Kızılhaç (Salib-i Ahmer) Cemiyeti’nin Çalışmaları, Atatürk Araştrrma Merkezi Dergisi, C XXXV, Güz 2019, S. 100, s. 330.

10 Akgün ve Uluğtekin, age., s. 109; Padişah'in Himayesinde Osmanh Kizllay Cemiyeti 1911-1913 Yillı̆̆r, haz. A. Zeki İzgöer - Ramazan Tŭg, Türkiye Kızılay Derneği, Ankara 2013, s. 135-143. Bunlardan Alman, İngiliz ve Fransız Kızılhaç örgütleri diğer Batılı kuruluşlara nazaran cephelerde daha aktif çalışmışlardı. Kizılay Arşivi (KA), 18/52, 8 Nisan 1913. Kızılhaç örgütleriyle ilgili yapılan yazışmalar için bk. Cumhurbaşkanlğ Devlet Arşivileri Başkanlğ̆, Osmanh Arşsivi (BOA), Hariciye Nezareti Siyasi Kısım Evrakı (HR. SYS), 2025/5, 2 Ekim 1912. 
Bunlar içerisinde Alman Salib-i Ahmer (Kızılhaç) Cemiyeti (Das Deutsche Rote $\left.K^{\prime} r e u z^{11}\right)^{\prime}$ nin İstanbul ve Edirne'de yürüttüğü çalışmaların ayrı bir yeri vardı. Savaşın daha ilk günlerinden itibaren ihtiyaca göre oluşturulan sağlık ekiplerini birbiri ardına Berlin'den İstanbul ve Edirne'ye gönderen DRK, Trablusgarp Savaşı'nda olduğu gibi Balkan Savaşları'nda da Osmanlı Hilal-i Ahmer Cemiyeti'ne büyük destek vermiştir.

Osmanlı cephesinde onlarca personeliyle (beş ekiple) sağlık çalışması yürüten Alman Salib-i Ahmer Cemiyeti’nin faaliyetlerine dair ülkemizde daha evvel birkaç araştırma $^{12}$ yapıldığı ancak, bu çalışmalarda verilen bilgilerin ağırlıklı olarak sağlık ekipleriyle sınırlı kaldığı, hasta ve yaralıların tedavileriyle ilgili hususlara pek değinilmediği ve hepsinden önemlisi, arşiv belgelerine yeterince yer verilmediği görülmektedir. Bu nedenle, Osmanlı topraklarına gönderilen Alman doktorların Berlin'e döndükten sonra kaleme aldıkları raporlar ile arşiv belgeleri ışığında Alman Salib-i Ahmer Cemiyeti'nin Balkan Savaşları esnasında İstanbul ve Edirne'de yürüttüğü sağlık çalışmaları burada detaylı bir şekilde değerlendirilecektir.

\section{Alman Kızılhaçı'nın İstanbul ve Edirne'ye Sağlık Ekiplerini Göndermesi}

Alman Kızılhaçı'nın Osmanlı cephesinde yardım çalışmaları 93 Harbi (1877-78 Osmanlı-Rus Savaşı) ile başlamış, Osmanlı Yunan Savaşı (1897) ile devam etmişti ancak, her iki savaşta da cepheye gönderilen sağlı personeli sayısı ve malzeme miktarı oldukça sınırlı kalmıştı. Trablusgarp Savaşı'nda ise DRK, Osmanlı Hilal-i Ahmer Cemiyeti'nin uluslararası Kızılay/Kızılhaç kuruluşlarına yaptığı yardım çağrısına olumlu cevap veren ve bu çağrıya en büyük desteği sağlayan yardım kuruluşlarının başında gelmiştir. Nitekim Berlin'deki Merkez Komitesi’nin

11 Bundan sonra Alman Salib-i Ahmer (Kızılhaç) Cemiyeti, Almanca karşıllı̆̆ "Das Deutsche Rote Kreuz"un kısaltılmış hali olan DRK şeklinde kullanılacaktır.

12 Feridun Frik, "Alman Kızılhaçının Trablus ve Balkan Harplerindeki Sıhhi Yardım Hizmetleri Eserinden Memleketimize Ait Notlar", Dirim, 30/8, Ağustos 1955, s. 344-351; Feridun Frik, "Alman Kızılhaçının Trablus ve Balkan Harplerindeki Sıhhi Yardım Hizmetleri Eserinden Memleketimize Ait Notlar", Dirim, 30/9, Eylül 1955, s. 388-392; Ertuğrul Göksoy, "Alman Profesör Kirschner'in 1912-1913 Balkan Harbi Sirasında Edirne'deki Gözlemleri”, 38. Uluslararası Tip Tarihi Kongresi Bildiri Kitabı, ed. N. Sarı - A. H. Bayat - Y. Ülman - M. Işın, XXVI/146, C III, s. 1453-1456; Nuran Yıldırım, Savaşlardan Modern Hastanelere Türkiye'de Hemşirelik Tarihi, Vehbi Koç Vakfi, İstanbul 2014, s. 125-127; Oya Dağlar, "Balkan Savaşları'nda İnsancıl Hukuk İhlallerine İki Örnek Olay: Alman Kızılhaç Ekiplerinin Karşlaştıkları Engeller ve Mısır Kızılay Vapuruna El Konması", Galatasaray Üniversitesi Hukuk Fakültesi Dergisi, S. 2, 2007, s. 235-257. 
kararıyla üç doktor, on iki hemşire ve hastabakıcı ile diğer yardımcı personelden oluşan sağlık ekibini bölgeye gönderen DRK, yaklaşık beş ay boyunca (1912 yllının Şubat ayı ortalarından Haziran ayının sonlarına kadar) Aziziye yakınlarında yer alan Garyan Kasabası'nda açtığı askerî hastane ile asker-sivil ayrımı yapmaksızın yüzlerce yaralı ve hastayı tedavi etmişti ${ }^{13}$.

Trablusgarp'taki çalışmalar henüz sona ermişti ki, Balkanlar'da savaş rüzgârı esmeye başlayınca DRK hazırık yapmaya başladı. Trablusgarp Savaşı'nda sadece Osmanlı cephesinde sağlık çalışması yürüten DRK, Balkan Savaşları'nda aynı anda dört farklı cepheye (Osmanlı, Bulgar, Sırp ve Yunan) sağlık ekibi gönderecek şekilde planlama yaptı. Merkez Komitesi'nin kararıyla Balkan Savaşları'nda DRK toplam 13 istasyonda çalışma yapacaktı. Bunların 2'si Bulgar, 1'i Yunan, 5’i Sırp ve 5'i de Osmanlı topraklarında çalışma yürütecekti. Osmanlı topraklarına gönderilecek ekipler (üçü İstanbul'da, ikisi Edirne'de) Harbiye Nezareti ve Osmanlı Hilal-i Ahmer Cemiyeti’nin uygun göreceği yerlerde sağlık hizmeti verecekti ${ }^{14}$.

Savaş başladıktan sonra DRK ilk sağlık ekibini 26 Ekim 1912 tarihinde Berlin'den İstanbul'a gönderdi ${ }^{15}$. İki günlük yolculuktan sonra İstanbul'a ulaşan ekibin başında Berlin'de cerrah olarak görev yapan Dr. Liebert bulunuyordu. Dr. Liebert'in ekibi kendisiyle birlikte sekiz personelden (Asistan Dr. Hitzler ile dört hastabakıcı ve iki hemşire) oluşuyordu. Ekip 28 Ekim'de İstanbul'a ulaştığında kendilerini Alman

13 Şimşek, agm., s. 330-335.

14 Dr. Kimmle, "Die Hilfsexpeditionen des Deutschen Roten Kreuzes nach Tripolitanen (1912) und nach dem Balkan (1912-1913)", Beiträge zur Kriegsheilkunde, Aus den Hilfsunternehmung der Deutschen Vereine vom Roten Kreuz Während des Italienisch-Türkischen Feldzuges 1912 und des Balkankriegs 1912-13, Hrsg: Central-Komitee der Deutschen Vereine vom Roten Kreuz, Springer Verlag, Berlin 1914, s. 12.

151906 yılında imzalanan Cenevre Sözleşmesi’nin 11. maddesine göre, uluslararası Kızılay/ Kızılhaç teşkilatları savaş esnasında yardım çalışması yürüteceği cepheleri, düşman ülkelerin hükûmetlerine veya askerî birimlerine bildirmek zorundaydı. DRK İstanbul ve Edirne'ye ekip göndereceği zaman bu durumla ilgili Bulgar, Yunan, Sırp ve Karadağ hükûmetlerini bilgilendirmişti. Aynı şekilde, Selanik'e gidecek DRK ekibiyle ilgili de Harbiye Nezareti'ne bilgi verilmişti. BOA, Dâhiliye Nezareti Siyasi Kısım Evrakı (DH.SYS), 1 12/7, 14 Teşrinievvel 1328/27 Ekim 1912. Bu hususla ilgili ayrıca bk. BOA, Bâb-1 Ali Evrak Odası (BEO), 4104/307794, 13 Teşrinievvel 1328/26 Ekim 1912; BEO, 4100/307451, 3 Teşrinievvel 1328/16 Ekim 1912. Ayrıca bk. KA, 94/28, 13 Teşrinievvel 132826 Ekim 1912; 94/35, 20 Teşrinievvel 13282 Kasım 1912. Cenevre Sözleşmesi’ne göre, uluslararası yardım kuruluşlarının cephelerde herhangi bir saldırıya uğramadan çalışabilme masuniyeti bulunmasına karşın Balkan Savaşları esnasında Sırp askerlerinin Hilal-i Ahmer çalışanlarına yönelik saldırılarda bulundukları görülmüştü. $B O A$, Hariciye Nezareti Londra Sefareti (HR.SFR.3..), 664/60, 3 Mart 1912. Ayrica bk. BOA,, BEO, 4123/309205, 17 Aralık 1912. 
Başkonsolosu G. Mertens, Gülhane Askerî Hastanesi Başhekimi Wieting Paşa ve Harbiye Nezareti'nde askeri sağlık hizmetlerinde müfettiş olarak görev yapan Albay (Oberst) Vollbrecht karşılamıştı ${ }^{16}$. Harbiye Nezareti bu ilk Alman sağlık ekibinin Dolmabahçe tepelerinde bulunan Gümüşsuyu Askerî Hastanesi’nde çalışmasını uygun buldu ve ekip kendilerine ayrılan odalara yerleşerek çalışmalara başladi $1^{17}$.

Savaşın ilerleyen günlerinde İstanbul'daki Alman sağlık personelinin raporlarına istinaden Berlin'deki DRK Merkez Komitesi ikinci bir ekip daha gönderme kararı aldı. Bu ekibin cerrahi müdahale konusunda tecrübeli olmasına dikkat edildi ve bu yüzden ekipte iki uzman cerrah yer aldı. Ekibin lideri Köln Şehir Hastanesi’nden Dr. Heinrich Luxembourg idi. Ekipte ayrıca Leipzig Üniversitesi’nde görevli Dr. Anton Jurasz ile dört hastabakıcı bulunuyordu. Bu ikinci sağlık ekibi 2 Kasım 1912 tarihinde Berlin'den ayrıldı ve iki günlük bir tren yolculuğunun ardından (4 Kasim'da) İstanbul'a geldi ${ }^{18}$.

Balkan Savaşı, doğu (Trakya) ve batı (Makedonya ve Arnavutluk) olmak üzere iki cephede meydana gelmiş; doğu cephesinde Bulgarlarla, batı cephesinde ise bütün müttefiklerle mücadele edilmişti. Bulgarlar, 21-23 Ekim'de Edirne ile Kırklareli arasında Sütoğlu ve Pınarhisar Muharebelerini, 28 Ekim-2 Kasım'da ise Lüleburgaz Savaşı'nı kazandılar. Bu yenilgi neticesinde Kırklareli Bulgarlara geçti ve Türk ordusu Çatalca hattına kadar çekilmek zorunda kaldı. Batı cephesinde de durum iyi değildi. Priştine, Serfiçe, Yenipazar, Karaferye, Vardar, İştib, Üsküp ve Manastır gibi asırlarca Türk hâkimiyetinde kalan bölgeler birkaç gün içerisinde kaybedildi. 23-24 Ekim'de Türk ordusu Komanova'da Sırplara yenildiği gibi Selanik’i korumakla görevli Tahsin Paşa da 35 bin kişilik ordusu ile Selanik’te Yunanlılara teslim oldu ${ }^{19}$.

16 Dr. Liebert, "Die I. Hilfsexpedition nach Konstantinopel”, Beiträge zur Kriegsheilkunde, Aus den Hilfsunternehmung der Deutschen Vereine vom Roten Kreuz Während des Italienisch-Türkischen Feldzuges 1912 und des Balkankriegs 1912-13, Hrsg: Central-Komitee der Deutschen Vereine vom Roten Kreuz, Springer Verlag, Berlin 1914, s. 455.

17 Gümüşsuyu Askerî Hastanesi, cephede ağır yaralanan askerlerin tedavilerine tam olarak cevap verebilecek bir donanıma sahipti. Alman sağlık ekibi hastaneye geldiğinde kendilerini Başhekim Seyid Bey karşıladı. Hastane yaklaşık 300-350 yatılı hastayı kabul edebiliyordu. Liebert, "Die I. Hilfsexpedition nach Konstantinopel..”, s. 457-460.

18 Bu ikinci sağlık ekibine kısa bir süre sonra Berlin'den Dr. Feist Wollheim de katılacaktır. Kimmle, "Die Hilfsexpeditionen des Deutschen Roten Kreuzes..", s. 14.

19 Öztuna, age., s. 264-265; Küçük, agm., s. 24. 


\section{Alman Salib-i Ahmer (Kızılhaç) Cemiyeti'nin İstanbul ve Edirne'de Yürüttüğü Sağlık Çalışmaları}

Her iki cephede ağır yenilgiler alan Türk ordusu büyük zayiat vermişti. Binlerce yaralı askerin yakın hastanelere taşınması gerekiyordu. Edirne'deki hastanelerin kapasitesi sınırlı olduğu için yaralı askerlerin büyük bir kısmı İstanbul'a gönderiliyordu. Harbiye Nezareti savaşın ilk günlerinden itibaren İstanbul'daki askerî hastaneleri daha iyi bir duruma getirdiği gibi Osmanlı Hilal-i Ahmer Cemiyeti de Ekim ayı içerisinde sekiz yeni askerî hastane açmış, savaş nedeniyle bazı mekteplerde ders yapılmadığı için cemiyet birkaç mektebi geçici olarak sağlık çalışmalarına tahsis etmişti ${ }^{20}$.

DRK'nin ikinci sağlık ekibi işte böylesine büyük sıkıntıların yaşandığı günlerde İstanbul'a geldi ve Gülhane Askerî Hastanesi Başhekimi Wieting Paşa'nın tavsiyesi üzerine Mekteb-i Sultanî ${ }^{11}$ binasına yerleşti. Sağlık çalışmaları burada yürütülecekti. Üç katlı olan bu geçici askerî hastanede aynı anda 500 yaralı asker tedavi edilebilecekti. Dr. H. Luxembourg'un ifadesine göre, cepheden İstanbul'a getirilen yaralı asker sayısı 18 bini bulmuştu ve mevcut şartlarda bütün bu yaralı askerleri tedavi etmek oldukça zordu. Her halükârda DRK sağlık ekibi 5 Kasım 1912 tarihinde çalışmalara başladı. Ekip cerrahi müdahale konusunda tecrübeli olduğu için cepheden gelen hafif yaralı askerleri Türk hastanelerine yönlendirirken, cerrahi müdahale gerektirecek şekilde ağır yaralı gelen hastaları ise tedavi ediyordu ${ }^{22}$.

Gepheden gelen yaralı ve hasta asker sayısındaki artış karşısında DRK üçüncü sağlık ekibini de İstanbul'a gönderme kararı almıştı. DRK sağlık personeli 25 Kasım 1912 tarihinde Berlin'den hareket etti ve birkaç gün sonra İstanbul'a ulaştı. Ekipte iki doktor (Breslau Üniversitesi'nden Cerrah Dr. Lothar Dreyer ve Bakteriyolog Dr. W. Geißler) ile on hemşire bulunuyordu. Ekibin Misır Hilal-i Ahmer Cemiyeti tarafindan idare edilen Beylerbeyi Hastanesi’nde çalışması uygun

20 Akgün-Uluğtekin, age., s. 105-108.

21 Cepheden İstanbul'a beklenenin de üzerinde yaralı gelmeye başlaması üzerine Osmanlı Hükûmeti, yaralı askerlerin tedavisi için İstanbul ve Galata Mekteb-i Sultanîleri'nin tahliye edilmesi ve geçici bir süre hastane olarak kullanılması istikâmetinde karar almıştı. BOA, Maarif Nezareti Mektubi Kalemi (MF.MKT), 1182/43, 20 Zilkade 1330/31 Ekim 1912; İstanbul Sultanî Mektebi'nin bu amaçla kullanımıyla ilgili bk. MF.MKT, 1182/79, 13 Zilhicce 1330/23 Kasım 1912.

22 Heinrich Luxembourg und Anton Jurasz, "Die II. Hilfsexpedition nach Konstantinopel", Beiträge zur Kriegsheilkunde, Aus den Hilfsunternehmung der Deutschen Vereine vom Roten Kreuz Während des Italienisch-Türkischen Feldzuges 1912 und des Balkankriegs 1912-13, Hrsg: Central-Komitee der Deutschen Vereine vom Roten Kreuz, Springer Verlag, Berlin 1914, s. 538-539. 
bulunmuştu. Giderlerini tamamen Mısır Hilal-i Ahmer Cemiyeti’nin finanse ettiği bu hastanenin başhekimi Alman doktor Prof. Reich (cerrah) idi ve DRK ekibi böyle bir ortamda daha rahat çalışma imkânı bulacaktı ${ }^{23}$.

Hastane Beylerbeyi Sarayı bitişiğinde hizmet veriyordu ve 200 yatak kapasitesine sahipti. DRK ekibi Beylerbeyi Hastanesi'nde yaklaşık üç ay görev yaptı. Daha sonra Osmanlı Hilal-i Ahmer Cemiyeti'nin açtı̆̆ı Vefa Hastanesi’ne (Vefa İdadi Mektebi) geçen ekip bir süre de burada hizmet etmiştir. Ekibin başında olan Dr. L. Dreyer ihtiyaç halinde Gülhane Askerî Hastanesi'nde Dr. Richard Bier (II. Abdülhamid'in özel doktoru) ile Dr. Vollbrecht'e yardım ediyordu. Cephede ağır yaralanan askerlerin önemli bir kısmı Gülhane'ye sevk edildiği için burada cerrahî uzmanlara büyük ihtiyaç duyuluyordu ${ }^{24}$.

Savaşın ikinci ayında (Kasım 1912) Türk ordusu her tarafta mağlup olmuş, Balkan devletleri Çatalca ile Adriyatik arasında bulunan Osmanlı topraklarını işgal etmişlerdi. Düşmana yalnız Edirne, Yanya ve İşkodra kaleleri dayanıyordu. Bulgar ordusu Çatalca önlerinde durdurulmuş, 3 Aralık'ta da Bulgarlarla mütareke imzalanmıştı ${ }^{25}$. Ingiltere Dışişleri Bakanı Sir Edward Grey’in girişimiyle 16 Aralık'ta Londra'da bir konferans toplanmış ve burada sulh şartlarının görüşülerek savaşın sona erdirilmesi hedeflenmişti. Ancak Londra Konferansı herhangi bir karar alınamadan 6 Ocak 1913 tarihinde dağıldı. 3 Şubat'ta Bulgarlarla akdedilen mütarekenin süresi bitince Çatalca ve Edirne Muharebeleri yeniden başladı. Bulgar ordusu Çatalca savunma hattını aşamadı ama 26 Mart'ta Edirne’yi ele geçirmeyi başardı ${ }^{26}$.

23 Lothar Dreyer, "Die III. Hilfsexpedition nach Konstantinopel, Chirurgische Beobachtungen in dem Lazarett des Ägyptischen Roten Halbmonds in Beylerbey und in dem Lazarett in Stambul", Beiträge zur Kriegsheilkunde, Aus den Hilfsunternehmung der Deutschen Vereine vom Roten Kreuz Während des İtalienisch-Türkischen Feldzuges 1912 und des Balkankriegs 1912-13, Hrsg: Central-Komitee der Deutschen Vereine vom Roten Kreuz, Springer Verlag, Berlin 1914, s. 596-598; Kimmle, "Die Hilfsexpeditionen des Deutschen Roten Kreuzes..”, s. 15; BOA, HR.SYS, 2026/1, 28 Kasım 1912. Mısır Hilal-i Ahmer Cemiyeti Balkan Savaşları esnasında sadece İstanbul'da değil Edirne'de de yardım çalı̧̧maları yürütmüştür. BOA, HR.SFR.3.., 692/21, 26 Nisan 1913.

24 Dreyer, "Die III. Hilfsexpedition nach Konstantinopel..”, s. 599-605.

25 Türk ordusunun mağlubiyeti ve Çatalca'ya kadar çekilmesi, mütarekeyle birlikte her iki taraftaki yaralı askerlerin bakımı ve orduların toparlanması için zaman kazandıkları gibi hususlar İstanbul Alman Büyükelçisi Freiherr von Wangenheim ile Berlin arasındaki yazışmalara da yansımışıt. Bu konular hakkında geniş bilgi için bk. Politisches Arschiv des Auswältigen Amtes Berlin (PAAA), R. 12466; R. 12476; R. 12479.

26 Bulgarlar Çatalca Muharebelerinde Türk ordusuna karşı kesin bir zafer kazanamayınca Edirne'yi

Belleten, Nisan 2021, Cilt: 85/Sayı: 302; 155-191 

Yürüttüğü Sağlık Çalışmaları

Edirne'nin elden çıkması şehirdeki hastanelerle bağlantının kesilmesine neden olmuş ve kuşatma esnasında sağlık personeli malzeme temini hususunda büyük sıkıntılar yaşamıştı. Edirne'de hükûmete ait bir hastane bulunuyordu. Bunun yanında Hilal-i Ahmer Cemiyeti'nin de daha savaşın başlarında açtığı bir hastane vardı. Hizmete girdiği ilk günlerde hastanenin bütün ihtiyaçları cemiyet tarafindan karşılanabiliyordu. Ancak kuşatma esnasında buraya personel ve sağlık malzemesi göndermek neredeyse imkânsız hâle gelmişti. Bunun üzerine cemiyet, Alman Kızılhaçı'na başvurarak Edirne'ye bir sağlık ekibi gönderilmesini talep etti²7.

Aynı şekilde, kuşatmanın uzaması ve yaralı askerlerin tedavilerinin zorlaşması üzerine Edirne müdafii M. Şükrü Paşa, Harbiye Nezareti aracılığıyla uluslararası yardım kuruluşlarından (Cenevre Sözleşmesi uyarınca) doktor ve tıbbî malzeme talebinde bulunmuştu. Hem Hilal-i Ahmer Cemiyeti’nin girişimleri, hem de M. Şükrü Paşa’nın talebi üzerine DRK Merkez Komitesi Edirne'ye bir sağlık ekibi gönderme kararı aldı. Ekibin başında daha evvel Almanya'dan İstanbul'a sağlık malzemesi ${ }^{28}$ getiren Prof. A. Hildebrandt (Berlin Üniversitesi'nden) bulunuyordu ve DRK ekibinin Bulgar topraklarından geçerek Edirne'ye ulaşması gerekiyordu. Ancak ekip Sofya'ya gelince, Bulgar hükûmeti DRK ekibine Sofya'daki sağlık çalışmalarına katılmalarını, şimdilik Edirne'ye gitmelerine müsaade edilmeyeceğini belirtti ${ }^{29}$.

almaktan başka çarelerinin olmadığını anlamışlardı. Şükrü Paşa idaresindeki Türk birlikleri Edirne'yi tam 5 ay 5 günlük Bulgar kuşatmasına karşı kahramanca muhafaza etmiş, ancak yiyecek ve sağlık malzemesi sıkıntısı had safhaya ulaşınca şehri Bulgarlar'a teslim etmek zorunda kalmıştı. Öztuna, age., s. 267-68; Küçük, agm., s. 24. Edirne’nin kuşatma esnasında yaşamış olduğu sıkıntılı günler ve özellikle sağlık çalışmalarına duyulan ihtiyacın had safhada olduğu gibi hususlara dair Alman Büyükelçisi F. von Wangenheim ile Berlin arasındaki yazışmalar için bk. PAAA, R. 12378 ; R. 12493.

27 Akgün - Uluğtekin, age., s. 109; Cemal Sezer - Ömer Metin, Hilal-i Ahmer Cemiyetinin Balkan Savaşlarnda Muhacirlere Yardimlan, Ankara 2016, s. 85.

28 Harbiye Nezareti 7 Kasım'da DRK'den İstanbul'daki Alman Elçiliği aracılığıyla çok sayıda yaralının tedavisi için sağlık malzemeleri talebinde bulundu. Talep DRK genel merkezine ulaşınca Prof. A. Hildebrandt ve Hastabakıcı B. Korth birkaç vagon dolusu sağlık malzemesini İstanbul'a getirip Türk doktorlarına teslim etmekle görevlendirildi. KA, 256/100, 7 Ocak 1913.

29 OA, HR.SYS, 2025/4, 3 Kanunuevvel 1328/16 Aralık 1912. Harbiye Nezareti ile Berlin Sefareti arasında yapılan görüşmeler neticesinde Edirne'de bulunan yaralı askerlerin tedavisi için DRK'den yeni bir "heyet- $i$ sthhiye" talebinde bulunulmuş, bu heyetin masraflarının da Osmanlı Hilal-i Ahmer Cemiyeti tarafindan karşılanacağı Berlin'deki Merkez Kurulu'na iletilmişti. BOA, BEO, 4120/308994, 21 Teşrinisani 1328/4 Aralık 1912. 
DRK'nin Sofya'da zaten bir istasyonu vardı ve burada Alman sağlık personeli Bulgar ordusuna hizmet ediyordu. Dr. A. Hildebrandt ve ekibi Sofya'da yaralı ve hasta Bulgar askerlerine yardım etmek yerine en azından Sofya ve Filibe'ye getirilen esir Türk askerlerine sağlık hizmeti vermeyi düşündüler. Dr. A. Hildebrandt Filibe'deki Bulgar makamlarıyla görüşerek yaralı Türk esirlerine yardım etmeye çalışıyor, yaralılara cerrahi müdahale gerekirse de Aleksander Gymnasium binasında hizmet veren Alman Hastanesi'ne yönlendiriyordu. Bulgar hükûmeti DRK ekibinin Edirne'ye geçmesine nihayet 29 Mart'ta müsaade etti. Ne var ki, şehir Bulgar ordusunun kontrolüne geçmişti ve ekibin burada rahat çalışması yine Bulgarlar tarafindan engellenecekti ${ }^{30}$.

DRK ekibi Edirne’ye geldiğinde kendilerini Osmanlı Hilal-i Ahmer Hastanesi Müdürü Bahaeddin Şakir karşıladı. Dr. A. Hildebrandt şehirdeki hastanelerin durumunu hızlı bir şekilde tespit ederek yürütülecek sağlık çalışmaları hakkında bir planlama yaptı. Ekip Berlin'den ayrılırken yanlarına sağlık malzemesi de almıştı ve onların getirdiği bu malzemeler sayesinde hem Hilal-i Ahmer Hastanesi, hem de şehirde hükûmete ait Merkez Hastanesi ${ }^{31}$ hasta ve yaralıların tedavilerine bir süre sorunsuz devam edebildi. DRK ekibi her iki hastanede Türk sağlık personeline yardımcı oluyordu. Edirne Bulgar işgalinde olsa da Dr. A. Hildebrandt yaralı Türk askerlerinin bir kısmını İtalyan Okulu'nda oluşturulan hastanede tedavi etmeye çalışmıştır ${ }^{32}$.

30 A. Hildebrandt, "Die I. Hilfsexpedition nach Adrianopel", Beiträge zur Kriegsheilkunde, Aus den Hilfsunternehmung der Deutschen Vereine vom Roten Kreuz Während des Italienisch-Türkischen Feldzuges 1912 und des Balkankriegs 1912-13, Hrsg: Central-Komitee der Deutschen Vereine vom Roten Kreuz, Springer Verlag, Berlin 1914, s. 661-681 ve 706; Osmanlı makamları, başlangıçta Dr. Hildebrandt'ı İstanbul'a getirmeyi düşündüyse de daha sonra Edirne'de kalmasının uygun olacağina karar vermiştir. BOA, BEO, 4157/311758, 17 Rebiulâhir 1331/26 Mart 1913. Ayrıca bk. BOA, HR.SYS, 112/7, 13 Cemaziyelevvel 1331/20 Nisan 1913.

31 Merkez Hastanesi’nde yatan yaralı ve hasta askerlerin sağlık ve iâşe masraflarının bir kısmını İngiliz Konsolosluğu karşılamıştı. OA, BEO, 4180/313467, 20 Mayıs 1329/2 Haziran 1913; OA, Meclis-i Vükelâ Mazbataları(MV), 177/ 104, 22 Mayıs 1329/4 Haziran 1913. İngiliz Konsolosluğu ayrıca, Edirne'nin Bulgarlarca muhasara edildiği esnada yaralanan Osmanlı askerlerinin tedavisi için teşkil edilen hastaneye ilk olarak 800 İngiliz lirası, daha sonra ise Osmanlı Bankası vasıtasıyla Edirne Müftüsü’ne teslim edilmek üzere 300 Osmanlı lirası yardımda bulunmuştu. BOA, BEO, 4183/313678, 30 Mayıs 1329/12 Haziran 1913. İngiliz Konsolosluğu'nun yanında İngiliz Salib-i Ahmer (Kızılhaç) Cemiyeti de Balkan savaşları esnasında İstanbul'da çalışma yürütmüştü. BOA, DH.ID, 164/1, 16 Receb 1331/21 Haziran 1913.

32 Hildebrandt, "Die I. Hilfsexpedition nach Adrianopel..”, s. 715-722. 
Dr. A. Hildebrandt'ın ekibinde bulunan Dr. Felix Teilhaber, İtalyan Okulu'nu hastaneye çevirerek burada sağlık hizmeti vermeye başladı. Aslında Edirne işgal edilince Bulgarlar İtalyan Okulu'nu esir alınan Türk askerlerinin ikameti için kullanmaya başlamışlardı. Ancak daha sonra burası boşaltılınca DRK ekibinin çalışabileceği bir şekilde düzenlendi. Hastanede malzeme eksikliği üst seviyedeydi ve ağır yaralı gelen hastaların burada tedavisi mümkün değildi. Bu yüzden cerrahi müdahale gerektiren vakalarda yaralılar şehirde bulunan Hilal-i Ahmer Hastanesi'ne, Merkezi Hastane'ye veya Alman Okulu bünyesinde oluşturulan ameliyathaneye gönderiliyordu. Edirne'de bugünlerde en büyük sıkıntı yetişmiş sağlık personelinin az olmasıydı. Bu yüzden Dr. F. Teilhaber iki Türk askerine acil müdahale ve hasta bakımı konusunda kısa süreli bir eğitim vererek onları çalışmalara dâhil etti. İlerleyen günlerde hastaneye iki Türk doktoru daha geldi ve İtalyan Okulu'ndaki çalışmalarda toplam 225 hastanın tedavisi sağlandı ${ }^{33}$.

Edirne'nin Bulgar işgaliyle birlikte şehirdeki sağlık çalısmaları büyük sıkıntılar içerisinde yürütülüyordu. Bulgarlar tarafından esir alınan Türk askerlerinin önemli bir kısmının tedaviye ihtiyacı vard ${ }^{34}$. DRK Merkez Komitesi bu durumu göz önüne alarak 8 Nisan 1913 tarihinde Edirne'ye Prof. Kirschner (Königsberg Üniversitesi'nden) idaresinde yeni bir sağlık ekibi daha gönderme kararı aldı. Bu ekip Berlin'den yola çıktığında Edirne'de bulunan Dr. A. Hildebrandt da şehirden ayrılarak Almanya'ya dönüyordu. DRK ekibi Edirne'ye ulaştığında ilk olarak Avusturya-Macaristan Konsolosu Dr. von Herzfeld ve Bulgar makamlariyla görüşmeler yaptı. Şehirde bulunan bir Türk mektebi ekibin sağlık çalışmaları için tahsis edildi. Dr. Kirschner'e burada Şark Demiryolu Şirketi'nde görev yapan Dr. Schneider ile Avusturyalı Hastabakıcı Maria ve Louders kardeşler yardım edecekti. İlerleyen günlerde bir Bulgar doktor ve birkaç Hilal-i Ahmer sağlık personeli de çalışmalara katıldı ${ }^{35}$.

33 Felix Teilhaber, "Die II. Hilfsexpedition nach Adrianopel, Beobachtungen und Tätigkeit auf dem Gebiete der Inneren Medizin”, Beiträge zur Kriegsheilkunde, Aus den Hilfsunternehmung der Deutschen Vereine vom Roten Kreuz Während des Italienisch-Türkischen Feldzuges 1912 und des Balkankriegs 1912-13, Hrsg: Central-Komitee der Deutschen Vereine vom Roten Kreuz, Springer Verlag, Berlin 1914, s. 754-756.

34 Bulgar hükûmeti Almanya'dan gelen DRK ekiplerini Sofya'da tutuyor ve onların Edirne'ye geçişlerine müsaade etmiyordu. Ekiplerin Sofya'dan Edirne'ye geçişleri kimi zaman Osmanlı idarecilerinin Batılı devletler nezdinde teşebbüste bulunmasıyla, kimi zaman da Sofya'daki Almanya Sefareti'nin girişimleriyle mümkün oluyordu. BOA, DH.SYS, 112/7, 7 Nisan 1329/20 Nisan 1913.

35 Dr. Kirschner, "Die II. Hilfsexpedition nach Adrianopel, Chirurgische und sonstige 


\section{DRK Ekiplerinin İstanbul ve Edirne'de Yürüttüğü Çalışmalar}

Balkan Savaşları başladığında Alman Kızılhaçı ayrım yapmaksızın savaşa giren bütün ülkelere yardım ulaştırmak için çalışma başlatmıştı. DRK savaş boyunca 13 istasyonda toplam 109 personelle (36'sı doktor, 20'si hastabakıc1, 50'si hemşire ve 3’ü de laboratuvar teknisyeni) sağlık hizmeti yürütmüs;; İstanbul, Belgrad, Sofya ve Atina'da merkezî birimler oluşturarak o bölgelerdeki sağlık kuruluşlarıyla işbirliği yapmayı prensip edinmişti. Ayrıca cemiyet, cephelerdeki duruma göre ihtiyaç duyulan sağlık malzemelerini doğrudan Berlin'den istemek suretiyle çalışmalarını büyük oranda aksatmadan devam ettirebilmişti. Savaş şartlarında Berlin'den gönderilen sağlık malzemelerinin Belgrad veya Sofya'ya ulaşması bir-iki haftayı bulurken İstanbul'a ulaşması neredeyse üç haftayı buluyordu. Sağlık malzemeleri Alman Demiryolu Şirketi'nin tahsis ettiği trenlerle DRK'nin Neubabelsberg'de bulunan ana deposundan alınarak istasyon merkezlerine ücretsiz ulaştırılıyordu ${ }^{36}$.

Ilk DRK ekibi Gümüşsuyu Askerî Hastanesi’ne geldiğinde burada kurulu bir düzen bulmuştu. Cerrahi müdahale ve sonrasindaki tedavilerin steril ortamlarda yapılabilmesi için hastanede her türlü imkân bulunuyordu. Ekip, 31 Ekim’i 1 Kasım'a bağlayan gece hastaneye 120 hastanın gelmesiyle birlikte hummalı bir şekilde çalışmalara başladı. Takip eden dört günde 200 yaralı daha geldi. Bu ilk yaralılar Gümüşsuyu Askerî Hastanesi’ne Karaağaç, Kırklareli (Kırkkilise), Vize ve Lüleburgaz'dan oldukça perişan bir vaziyette gelmişti. Tedavileri tamamlanan askerler taburcu edilmesine rağmen hastanede tedavi gören hasta sayısı hiçbir zaman 250'nin altına düşmemiştir. Çatalca hattında yaralanan Türk askerleri İstanbul'a gelmeye başlayınca çalışmalar tekrar yoğunlaşmış, hafif yaralı olanlar Hilal-i Ahmer'e ait hastanelere yönlendirilirken ağır yaralı olanlara ise burada müdahale edilmişti ${ }^{37}$.

Beobachtungen in Adrianopel", Beiträge zur Kriegsheilkunde, Aus den Hilfsunternehmung der Deutschen Vereine vom Roten Kreuz Während des Italienisch-Türkischen Feldzuges 1912 und des Balkankriegs 1912-13, Hrsg: Central-Komitee der Deutschen Vereine vom Roten Kreuz, Springer Verlag, Berlin 1914, s. 744-748.

36 DRK, savaşın altı aydan fazla sürmeyeceğini öngörmüş, hazılıklarını ve savaş tedarikini de buna göre yapmıştı. Dolayısıyla savaşın uzaması DRK için maliyetin artmasına neden olmuştur. Kimmle, "Die Hilfsexpeditionen des Deutschen Roten Kreuzes..", s. 19-20.

37 İlk sağlık ekibinden bazı hastabakıcılar ilerleyen günlerde hastalık veya diğer nedenlerden dolayı Almanya'ya dönünce DRK onların yerine hemen yeni sağlık personeli gönderek çalışmaların aksamadan devam ettirilmesine büyük önem vermiştir. Liebert, "Die I. Hilfsexpedition nach Konstantinopel..”, s. 460-462. 

Yürüttüğü Sağlık Çalışmaları

Çalışmalar esnasında ikinci DRK ekibine Haydarpaşa Askerî Hastanesi’nde eğitim gören iki talebe de yardım ediyordu. Ekipte bulunan iki hastabakıcı operasyonlarda doktorlara yardım ederken diğer ikisi pansuman, sargı ve yaralıların her türlü bakımı gibi işlerle ilgileniyodu. 19 Aralık 1912 tarihinde mektep yine aslî amacına uygun bir şekilde kullanılmak üzere okul yönetimine devredilince DRK ekibi buradaki hastaları farklı hastanelere sevk ederek İstanbul Baytar Mektebi ${ }^{38}{ }^{3}$ ne taşındı. Aynı şekilde, burada da kısa süre içerisinde düzen kuran ekip çalışmalara başladı. Mart ayının ortalarına kadar İstanbul'da kalan ikinci ekip yaklaşık dört aylık sürede 381 yaralının tedavisiyle ilgilenmişti. Bu yaralıların yarıdan fazlasına cerrahi müdahale yapılmış, ancak bunların 34 'ü hayatını kaybetmişti ${ }^{39}$.

İstanbul'a gelen üçüncü ekipteki personelin bir kısmı (Dr. Geißler, A. Weidner ve A. Zöwe) salgın hastalıkla mücadele etmek üzere Ayastefanos (Yeşilköy)'ta bulunan karantina kampına gitmişti. Yaklaşık altı hafta burada kalan ekip salgının azalmaya başlaması üzerine tekrar Beylerbeyi Hastanesi'ne döndü. Dr. Dreyer yönetimindeki diğer grup ise hemen çalışmalara başlamıştı. Ameliyathanenin teşkili ve hastanede steril ortamın oluşturulmasından sonra ekibin beraberinde getirdiği küçük röntgen cihazi $^{40}$ (Gebbert u. Schall-Berlin) kurularak yaralı tedavisine başlandı. DRK ekibi Beylerbeyi'nde yaklaşık üç ay görev yaptıktan sonra Hilal-i Ahmer Cemiyeti tarafindan tanzim edilen Vefa Hastanesi ${ }^{41}$ 'ne geçti. Hilal-i Ahmer, hastanede bütün ihtiyacı karşılayacak bir ortam hazırladığından Alman sağlık ekibi yanlarında sadece cerrahi müdahale için gerekli bazı aletleri getirmiştir. DRK ekibi burada da ağır yaralı askerlerle ilgilenmiş, durumu iyi olan askerleri diğer hastanelere sevk etmiştir. Dolayısıyla, DRK doktorları İstanbul'daki çalışmaları boyunca yaralılar arasında hafif ve ağır ayrımı yaparak daha fazla askerin sağlığına kavuşacağına inandığı için çalışmalarını büyük oranda bu anlayışa göre yürütmüştür ${ }^{42}$.

38 Balkan Savaşları esnasında hastaneye çevrilen mekânlardan birisi de İstanbul Baytar Mektebi'ydi. BOA, BEO, 4229/317118, 5 Zilhicce 1330/15 Kasım 1912.

39 Luxembourg und Jurasz, "Die II. Hilfsexpedition nach Konstantinopel..”, s. 539-547.

40 Yaraların tedavisinde doğru teşhis önemli bir yere sahip olduğundan DRK, İstanbul ve Edirne'deki çalışmalarda kullanılmak üzere ekiplerle birlikte röntgen cihazları (İstanbul'a iki, Edirne'ye bir) da göndermişti. Liebert, "Die I. Hilfsexpedition nach Konstantinopel..”, s. 459.

4124 Ekim 1912 tarihinde Osmanlı Hilal-i Ahmer Cemiyeti tarafindan açlan Vefa (Vefa İdadi Mektebi) Hastanesi, savaşta yaralanan askerlerin tedavisi için İstanbul'un farklı semtlerindeki mekteplerin hastaneye çevrilmesiyle oluşturulmuş askeri hastanelerden birisiydi. Akgün - Uluğtekin, age., s. 104.

42 Dreyer, "Die III. Hilfsexpedition nach Konstantinopel..”, s. 598-605. 
Edirne 26 Mart 1913 tarihinde yaklaşık beş aylık bir savunmadan sonra Bulgarlar'ın eline geçmişti. Savaşın başladığı günden şehrin düşü̆ğü tarihe kadar sağlık çalışmalarında bazı aksaklıklar yaşansa da hem hükûmete, hem de Hilal-i Ahmer'e ait hastanede yaralı ve hastaların tedavisi devam ettirilmişti. Ancak, Edirne'nin işgaliyle birlikte hastanelerde sağlı malzemesi sıkıntısı üst seviyeye ulaşmıştı. Bulgarlar İstanbul'dan gönderilecek yardımlara engel oldukları gibi Avrupa'dan gelen yardımları da önlemeye çalışıyordu ${ }^{43}$. DRK ekibi Edirne'ye ulaştığında şehrin savunması esnasında yaralanan askerlerin acilen tadavi altına alınması gerektiğini görmüştü. Hâlihazırda Türk hastaneleri faaliyetlerine devam ediyordu. Bu süreçte İtalyan ve Alman okullarında oluşturulan hastanelerde de yaralı askerlerin tadavisine başlandı. DRK ekibi Edirne'de yaralı askerlerin yanında halka da sağlık hizmeti sunmuş ancak, esir Türk askerleriyle özel olarak ilgilenmişlerdi ${ }^{44}$.

İkinci ekibe tahsis edilen mektepte Dr. Kirschner ve ekibi yaklaşık 300 yaralı Türk askerine hizmet vermişti. Hastane (mektep) 100 yatak kapasitesine sahipti ve burada bir ameliyathanenin kurulması neticesinde Dr. Kirschner cerrahi müdahale gerektiren yaraları tedavi etmeye başladı. Bulgarların engelleme ve her türlü zorluk çıkarmalarına rağmen ikinci DRK ekibi de esir Türk askerleriyle ilgilenmişti. Mayıs ayının başlarında İtalyan ve Alman okullarında teşkil edilen hastaneler kapatılınca burada bulunan ilaç, sargı malzemeleri ve diğer sağlık ekipmanlarını Türk hastanelerine nakletmek isteyen DRK ekibine Bulgarlar müsaade etmemiş ve bütün malzemelere el koymuştur ${ }^{45}$.

\section{Yaralıların Tedavisi}

93 Harbi sonrasında Osmanlı Devleti Alman silah şirketleriyle yakın temas kurmaya başlamış ve Balkan Savaşları öncesine kadar Krupp, Ehrhardt ve Mauser gibi Alman şirketlerine yüklü miktarlarda silah ve top siparişi vermişti. Balkan ülkeleri de aynı şekilde Berlin Antlaşması'ndan sonra silahlanmaya başlamış,

43 Mesut Çapa, "Balkan Savaşı'nda Kızılay (Osmanlı Hilâl-i Ahmer Cemiyeti)", Ankara Üniversitesi Osmanl Tarihi Araştırma ve Uygulama Merkezi Dergisi (OTAM), S. 1, Ankara 1990, s. 92.

44 Hildebrandt, "Die I. Hilfsexpedition nach Adrianopel..", s. 674; Teilhaber, "Die II. Hilfsexpedition nach Adrianopel, Beobachtungen und Tätigkeit..”, s. 756.

45 Bulgar yönetimi DRK ekibine, bu malzemeleri savaş ganimeti olarak aldıklarını belirtmiştir. Kirschner, "Die II. Hilfsexpedition nach Adrianopel..", s. 753. 


\section{Alman Salib-i Ahmer (Kızılhaç) Cemiyeti'nin İstanbul ve Edirne'de Yürüttüğü Sağlık Çalışmaları}

Fransız (Schneider), Rus ve Alman silah şirketlerinden piyade tüfeği, silah ve seri atışlı toplar satın alarak Balkanlar'da çıkacak olası bir savaşa hazırlık yapmışlardı ${ }^{46}$.

$\mathrm{Bu}$ şekilde teçhiz edilen orduların kullandığı modern ve etkili silahlar ağır ve kimi zaman ölümcül yaralara neden oluyordu. Örneğin Bulgar ordusu Fransız Schneider sahra bataryaları ve $75 \mathrm{~mm}$ 'lik Alman Krupp toplarıyla; Karadağ ordusu aynı şekilde Krupp topları ile kasalı ve üç yivli Rus tüfekleriyle mücehhezdi ${ }^{47}$. Bulgarların kullandığ küçük kalibreli mermiler $8,2 \mathrm{~mm}$ çapında, $31,8 \mathrm{~mm}$ uzunluğunda ve 15,8 gr ağırlığında idi. Yine Bulgar ordusunda bulunan şarapnel topları 10 gr ağırlığında ve yaklaşık $12 \mathrm{~mm}$ çapında idi. Şarapnel topuyla yaralan 290 Türk askerinin 98'inde bu toplar vücutlarından bir bütün halinde, yani parçalanmadan çıkarılmıştı. Şarapnel parçaları ise daha çok deri yüzeyinde tahribata neden oluyor ve kimi zaman vücutta tedavisi zor yaralar açıyordu. Cepheden getirilen hastaların büyük bir kısmı kurşun yarası (schußverletzung) olanlardan meydana geliyordu. Sadece Gümüşsuyu Askerî Hastanesi'ne 753 kurşun yarası olan asker getirilmiş; bunların 425'i küçük kalibreli silahlarla, 311’i şarapnel topuyla ve 17'si Martini ve benzeri tabanca mermisiyle yaralanmışt1 ${ }^{48}$.

Bulgar tarafinda yaralanan askerler (Türklerin silahlarından çıkan mermilerle) daha kolay tedavi edilirken, Bulgarların yaraladığı Türk askerlerinin tedavileri oldukça zor oluyordu. Çünkü Bulgar askerleri ogival mermi kullandıklarından bunlar isabet ettiği vücutlarda ağır tahribata neden oluyordu. Cephede yaralanan bir askerin hastaneye ulaştırllip tedavisine başlanması neredeyse 2-4 günü bulabiliyordu. Bu yüzden sağlık birimlerine gelen yaraların yaklaşık \%90'ı enfeksiyon kapmış bir vaziyetteydi ve bu hususa bağlı olarak beş hastadan biri yolda veya hastaneye gelir gelmez ölüyordu. Diğer yandan, düşman mermisiyle

46 Örneğin Bulgaristan, savaşta kullandığı topların \%75’ini, top cephane fünyelerinin tamamını, cephanelerin ise \%90'ını Alman Krupp Şirketi’nden satın almıştı. Serdar Dinçer, Birinci Dünya Savaşı'nn 100. Yilnda Alman Dışişleri Belgelerinde Krupp'un Bitmeyen Balkan Savaşı, Sürgün ve Soykirm, Favori Yayınları, Ankara 2014, s. 301; Fahri Türk, Türkiye ile Almanya Arasindaki Silah Ticareti (1871-1914), IQ Kültür Sanat Yayıncilık, İstanbul 2012, s. 92 ve 280-281. Bulgaristan, Sirbistan, Yunanistan, Romanya ve Karadağ’ın 20. yüzyılın başlarından itibaren uygulamaya koydukları ahz-1 asker düzenlemeleri ile sahip oldukları silahların özellik ve menşei hakkında detaylı bilgi için bk. Rifkl, age., s. 3-25.

47 Rifkı, age., s. 24-25.

48 Liebert, "Die I. Hilfsexpedition nach Konstantinopel..", s. 468-469. DRK doktorlarmın raporlarına göre, dört Balkan ülkesinin ordusunda hala eski ogival mermi kullanıldığından Türk askeri uzun mesafeden etkisiz hale getirilebiliyordu. Hildebrandt, "Die I. Hilfsexpedition nach Adrianopel..", s. 728. 
yaralanan birçok Türk askeri vurulduğu yerde kalmış ve bunlar ya açlıktan, ya da yorgunluktan bitkin düşerek hayatını kaybetmişti. Bu şekilde kaderine terkedilen yaralı Türk askeri sayısı, DRK kayıtlarına göre, 400 civarında idi ${ }^{49}$.

Kurşun yaralarının tedavisiyle ilgili DRK ekibini zorlayan en önemli sorun cepheden getirilen askerlerin büyük bir kısmında yaraların enfeksiyon kapmış olmasıydı. Küçük kalibreli mermi yaraları veya şarapnel parçalarının neden olduğu yaralarda dikkat edilmesi gereken husus kurşun delikleri ve yaraların enfeksiyon kapmamasıdır. Ne yazık ki, yaralanan Türk askerlerine ilk bandaj uygulamasının hatalı yapılması veya bir diğer ifadeyle, yaralara steril olmayan malzemelerle ${ }^{50}$ tampon yapılması nedeniyle askerlerin büyük bir kısmı hastaneye ağır vaziyette geliyordu. Aynı şekilde, çeşitli nedenlerle savaş esnasında ayă̆ında veya kolunda kırık oluşanların kırık bölgesi uygun bir şekilde sarılmadan hastaneye sevk edildiği için askerler saatlerce, hatta günlerce acı çekerek yolculuk yapıyordu. Bununla birlikte, Haydarpaşa Askerî Hastanesi Başhekimi Wieting Paşa ile Emin Paşa'nın üstün gayretleri sayesinde yaralı askerlerin Çatalca hattından İstanbul'daki hastanelere nakli genel olarak sorunsuz devam etmiş, Hilal-i Ahmer Cemiyeti'nin de yardımlarıyla pek çok asker ağır yaralı olmasına rağmen ameliyathanesi bulunan hastanelere ulaştırılabilmiştiti ${ }^{51}$.

Cepheye yeterli gıda malzemelerinin nakledilememesi ve buna bağlı olarak Türk askerinin düşmanla birlikte "midesiyle de harp etmesi" yüzünden savaşın daha ilk birkaç haftasında bozgun haberleri gelmeye başladı. Yeterli beslenememe ve Bulgar ordusuna nispetle Türk askerlerinin soğuk hava şartlarından olumsuz etkilenmesi de başarısızlığımızın en büyük nedenleri olarak ifade edilebilir ${ }^{52}$. Bu

49 Hildebrandt, "Die I. Hilfsexpedition nach Adrianopel..", s. 714; Troçki, Balkan Savaşlar, s. 395; Bogdan Filov, Balkan Savaşlar Günlïğü, haz. Hüseyin Mevsim, Timaş Yayınları, İstanbul 2014, s. 28.

50 Kimi zaman yaralı askerlerin nakli esnasında yaraların üzerine örtülen ve steril olmayan kuru kumaşlar da enfeksiyona davetiye çıkarıyordu. Bu kumaşlar bir müddet sonra yaralara yapışıp kuruduğundan nakil esnasında askerlere büyük acı veriyordu. Liebert, "Die I. Hilfsexpedition nach Konstantinopel..”, s. 470.

51 Luxembourg und Jurasz, "Die II. Hilfsexpedition nach Konstantinopel.." s. 545; Dreyer, "Die III. Hilfsexpedition nach Konstantinopel..”, s. 609. Balkan Savaşları'nda Türk askeri her bakımdan büyük sıkıntılar çekmiştir. Bunlar içerisinde yaralı Türk askerlerinin bazı köylerde kaderine terk edilmesi ve en ufak yardımın dahi esirgenmesi gibi hadiseler, bu savaşın hazin yüzünü göstermesi açısından önemlidir. Yüzbaşı Osman Nuri, Balkan Harbi Hatırat, haz. Zeynep Kerman, Dergâh Yayınları, İstanbul 2014, s. 26.

52 Sabis, age., s. 57.

Belleten, Nisan 2021, Cilt: 85/Sayı: 302; 155-191 


\section{Alman Salib-i Ahmer (Kızılhaç) Cemiyeti'nin İstanbul ve Edirne'de Yürüttüğü Sağlık Çalışmaları}

noktada DRK sağlık çalışanları, hastaneye yaralı veya hasta bir vaziyette getirilen askerlerin genelde bitkin ve günlerce aç kaldığını ${ }^{53}$ rapor etmişlerdi. Bulgar, Sırp ve Yunan cephelerinde askerlere verilen günlük istihkak Osmanlı cephesinde verilenlerle kıyaslandığında, Türk askerlerlerinin ne denli güç şartlara tahammül etmek zorunda kaldığı daha iyi anlaşılacaktır ${ }^{54}$.

Bu durumu göz önüne alan DRK ekipleri hastanelerde yaralı ve hasta askerlerin beslenmesine azami dikkat etmiş, imkân dâhilinde askerlere her gün iki öğün yemek vermeye çalışmıştır. Sabahları çoğu hastaya çay verilirken, bazı hastalara süt ve yumurta dağıtılmıştı. Genellikle pirinç ve koyun etinden oluşan yemeklere ek olarak her hastaya günde iki siyah ekmek verilirdi. Tütün ise her hastaya düzenli olarak dağıtılırdı ${ }^{55}$.

Edirne'nin 26 Mart 1913 tarihinde düşmesiyle şehirdeki Türk askerleri için zorlu günler başlamışt ${ }^{56}$. Bulgarlar esir aldıkları Türk askerlerinin bir kısmını farklı köylerde (Bosnaköy/Bosnakoi ve Ahırköy/Ahirkoi) tutuyorlardı. Bu köylerdeki esir sayısı 8 bine ulaşmıştı. Kamplarda esirlerin durumu oldukça kötü idi ve askerler kaderlerine terkedilmiş bir vaziyette açık alanlarda barınıyordu. Sadece ağır hastalar için çadır tahsis edilmişti ancak, bu çadırlarda ne bir yatak, ne de bir battaniye bulunuyordu. DRK ekibi esirleri ziyaret ettiklerinde çadırlar içerisinde kuru zeminde yatan ağır yaralı Türk askerlerini görünce bunların hastanelere nakli için gerekli izni Bulgar makamlarından güçlükle alabilmişti57

53 Alman Büyükelçisi Freiherr von Wangenheim 7 Kasım 1912 tarihinde Berlin’e gönderdiği mektubunda, Türk cephesindeki kumandanlar eğer emri altında bulunan askerlere yeterince yiyecek temin etmiş olsalardı, savaşın kaderinin değişeceğini ve askerlerin mukavemet gücünün artarak savaşmaya devam edebileceğini ifade etmişti. Zira, Kırkkilise (Kırklareli) ve Lüleburgaz Muharebelerinde Türk askerleri 4-5 gün boyunca açlık çekmişlerdi. Wangenheim mektubunda ayrıca, Bulgar ordusu karşısında aç ve susuz bir vaziyette Çatalca'ya kadar çekilen binlerce Türk askerinde moral bozukluğu ve isteksizliğin hâkim olduğunu belirtmiştir. PAAA, R. 12364, 7 November 1913.

54 Örneğin Bulgar cephesinde her bir askere günlük $1 \mathrm{~kg}$ ekmek, $400 \mathrm{gr}$ et, $100 \mathrm{gr}$ pirinç, fasulye, mercimek veya $200 \mathrm{gr}$ patates, $500 \mathrm{gr}$ kurutulmuş erik, $500 \mathrm{gr}$ tereyağı veya diğer yağlar, $3 \mathrm{gr}$ baharat, 29 gr tuz, 5 gr kahve ve 30 gr şeker veriliyordu. Hildebrandt, "Die I. Hilfsexpedition nach Adrianopel..", s. 670.

55 Liebert, çalışmalara dair notlarında Türk askerlerinin tütün kullanma alışkanlığına dair şu ifadeleri kullanmıştır: "Pek çok Türk askeri Doğu'ya has sakinliğine rağmen, muhtemelen aşın sigara içmenin bir sonucu olarak oldukça gergindi. Öyle ki, çoğu hasta gün boyunca sigara i̧̧meye devam ediyor, bazzlan ağızlarnda sigara ile ölïyordu.” Liebert, "Die I. Hilfsexpedition nach Konstantinopel..”, s. 464.

56 Yusuf Hikmet Bayur, Türk İnklabı Tarihi, C II/Kısım 2, Türk Tarih Kurumu Yayınları, Ankara 1983, s. 313-314 ve 482-491.

57 Kirschner, "Die II. Hilfsexpedition nach Adrianopel..”, s. 752-753. 
Bulgarların esir Türk askerlerini tuttuğu bir diğer köy de Knaşevo (Knaschevo) idi. Burada bir kışlaya yerleştirilen esirlerin sayısı 400 civarındaydı. Bunlardan kolera, dizanteri ve tifüs hastaları binanın bodrum katına, diğerleri ise zemin ve birinci kata yerleştirildi. Bu askerlerin sağlık ihtiyacı iki doktor, dört tıp öğrencisi ve iki hemşireden oluşan Hilal-i Ahmer heyeti tarafindan karşlanıyor, DRK ekibi de onlara yardım ediyordu. DRK doktorlarının raporlarına göre, esirlerin hali içler acısıydı ve yaralıların bakımı pek de iyi yapılmıyordu. Bazı kaynaklarda Bulgarların esir Türk askerlerine gayet yardımsever yaklaştıkları yönündeki beyanlara ${ }^{58}$ karşın DRK raporlarında, Bulgarların Türk esirlere tavrı ve onlara beslediği his nefret dolu idi. Alman ekibinin Türk askerlerine yardım etmesi hem Bulgar ordusu, hem de Bulgar halkı tarafindan pek de hoş karşılanmıyor, ekiptekilerin fotoğraf çekmelerine bile müsaade edilmiyordu. Her yüz esire bir tuvalet tahsis edilmişti ve temizliğe pek riayet edilmediğinden bu durum salgın hastalıklara davetiye çıkarıyordu. Kış günlerinde geceleri hava sıcaklığı sıfırın altında $15^{\circ}$ ye kadar düştüğünden birçok esirin ayağı donuyor, takip eden günlerde ise büyük bir kısmı hayatını kaybediyordu. 1912/1913 kışında esir edilen ve Filibe'de tutulan 1.200 Türk askerinden neredeyse 800'ünün şehit olduğu tespit edilmişti ${ }^{59}$.

Balkan Savaşları'nda Osmanlı ordusunun ağır yenilgi almasının nedenlerinden biri de etkin ve ihtiyaca cevap verebilecek insan gücünü seferber etme yeteneğindeki yetersizlik ve seferber edilebilen gücün de verimli kullanılamamasıydı. Osmanlı ordusu düşman ordularına kıyaslandığında asker sayısı bakımında kötü durumda değildi ancak, redif kuvvetlerinin talimden yoksun oluşu, nakil vasıtalarının yetersizliği, askere yeterince gıda malzemesi ulaştırılamaması ve ordunun ricat, yani geri çekilme konusunda hazırlıksız ve plansız hareket etmesi gibi hususlara bağlı olarak ordu büyük kayıplar vermişti ${ }^{60}$. Örneğin, savaşın ilerleyen günlerinde havanın soğumaya başlamasıyla birlikte Türk askerlerinin mukavemeti azalmaya

58 Troçki, Balkan Savaşlan..., s. 289-295.

59 Hildebrandt, "Die I. Hilfsexpedition nach Adrianopel..", s. 674-684.

60 Sabis, age., s. 101-115. Balkan Savaşları öncesinde askere alma ve seferberlik hususlarında Balkan ülkeleri güncel ve ihtiyacı karşılayacak yeni düzenlemeler yaparken, Osmanlı Devleti daha evvel yapılmış ve pek çok eksiği bulunan düzenlemelere göre hareket ettiğinden büyük sorunlar yaşamıştı. Sadece ülkelerin nüfuslarına nispeten seferber ettikleri asker sayılarına ve savaş öncesi yapılan düzenlemelere bakıldığında bile Balkan ülkelerinin harbe daha disiplinli ve hazırlıklı girdikleri öne çıkmaktadır. Mehmet Beşikçi, "Balkan Harbi’nde Osmanlı Seferberliği ve Redif Teşkilatının İflası", Bir Asır Sonra Balkan Savaşları, haz. Mustafa Çalık, Cedit Neşriyat, Ankara 2015, s. 55-69; H. C. Seppings-Wright, Trablusgarp ve Balkan Savaşlarnda Hilal Altında İki Yıl, çev. Derin Türkömer, Türkiye Işs Bankası Kültür Yay., İstanbul 2013, s. 176. 

Yürüttüğü Sağlık Çalışmaları

başlamış ${ }^{61}$, cepheden bir biri ardına donma (özellikle kangren/ayak yanığ1 ${ }^{62}$ ) şikâyetleri gelmeye başlamıştı. Bu rahatsızlıklar Türk askerinin uzun süre, bazen günlerce suda, çamurda, siperlerdeki karda veya soğuk havalarda nemli zeminlerde beklemesinden kaynaklanıyordu. Orduda ayakkabı yetersizdi ve dağıtılanlar da çabuk yırtılıyordu. Bazı askerler dar ayakkabı giymek zorunda kalıyor, bazıları ise çorap bulamıyordu ${ }^{63}$.

Aslında donma vakaları Bulgar, Sırp ve Yunan cephelerinde de yaşanıyordu ancak, Türk tarafinda bu tür şikâyetle sağlık birimlerine başvuranların sayısı bir hayli yüksekti. Bunun birkaç nedeni vardı. Ilki, askerlerin çorap ve botları ıslandığı halde ayaklarını çıkartıp kurutma imkânı bulamamalarıydı ve ıslanan ayaklar uzun süre bu şekilde kaldığından kangren vakalarına davetiye çıkarıyordu. İkincisi, askerler saatlerce ayakta durduklarından bacaktaki kan dolaşımı sağlıklı bir şekilde devam etmiyordu. Batılı devletler savaş esnasında askerlerin baldırlarını "piyade sargısı" ile sarıp, uzun çizme giymelerini temin ederek onların vücut dirençlerini artırıyor ve sağlıklı bir şekilde uzun süre ayakta kalmalarını sağlayabiliyordu. Oysa Türk ordusunda böyle tedbirler alınamadığından askerlerin dayanma gücü kısa sürede zayıflıyordu. Bunların yanında, Türk askerlerinin aşırı sigara tüketimi de kangren vakalarının artışına etki ediyordu. Çünkü gün içerisinde oldukça fazla tütün tüketimi damar sisteminin zayıflamasına ve bacaklardaki direncin daha çabuk azalmasına neden oluyordu ${ }^{64}$.

Kangren şikâyetiyle gelen askerler genelde Haydarpaşa, Gülhane veya Gümüşsuyu Hastanelerine yönlendiriliyordu. Bu tür şikâyetle sadece Gümüşsuyu Askerî Hastanesi'ne gelen asker sayısı 72 idi. Bunların 56'sı iki ayağından, 16’sı ise tek ayağından rahatsızdı. Bu hastaların 47'sinde ateş parmak uçlarıyla sınırlı iken 9 vakada ayaklar kısmen, 14 vakada ise tamamen kangrenli idi. Geriye kalan 2 hastanın sadece birer parmaklarında ateş vardı. Bu askerlerin çoğu dizanteri, kolera ve diğer hastalıkların da etkisiyle hızla zayıflıyordu. Bu şikâyetle gelenlerin ağır ağrıları olduğundan bunu hafifletmek için hastalara bazen günlerce morfin veriliyordu. Gümüşsuyu Askerî Hastanesi’ne ayak yanığı/kangren rahatsızlığıyla

61 Bulgar tarafinın Türk ordusuna nazaran kış şartlarına daha dayanıklı olduğuna dair görüşler için bk. Dinçer, age., s. 339.

62 Dreyer, "Die III. Hilfsexpedition nach Konstantinopel..”, s. 614-615.

63 Liebert, "Die I. Hilfsexpedition nach Konstantinopel..”, s. 532. DRK sağlık çalışanlarına göre Türk askerlerinin elbiseleri Bulgar askerlerine kıyasla kış şartlarına uygun değildi. Kirschner, "Die II. Hilfsexpedition nach Adrianopel..", s. 751.

64 Luxembourg und Jurasz, “Die II. Hilfsexpedition nach Konstantinopel..”, s. 594. 
gelen hastalardan 8'inin tek ayağı, 9'unun ise her iki ayağı kesilmişken, 13'ü diğer hastalıkların da etkisiyle hayatını kaybetmiş̧ti ${ }^{65}$.

Savaşın başlamasıyla birlikte İstanbul'a gönderilen DRK sağlık ekipleri görev yaptıkları süre zarfinda hastanelere getirilen askerlerin rahatsılıklarını ve tedavi süreçlerini teferruatlı bir şekilde kayıt altına almışlardı. Gümüşsuyu Askerî Hastanesi'ne gelen ilk DRK ekibi 6,5 aylık çalışma süresince yaklaşık bin yaralının/hastanın tedavisi ile ilgilenmişti. Bunların büyük bir kısmını (neredeyse \%80) kurşun/şarapnel yaralanmaları, geri kalan kısmını ise dâhili hastalıklar (ağılıklı olarak bağırsak hastalıkları) oluşturuyordu. Bunların dışında burkulma, kemik kırılması ve çıkık gibi rahatsızlıklardan 20, ayak yanı̆̆ı/kangren şikâyetiyle de 72 hasta tedavi altına alınmıştı. Tedavi edilen askerlerin büyük bir kısmı sağlıklarına kavuşmuş ancak, hastaneye ağır bir vaziyette gelen 53 yaralı hayatını kaybetmişti ${ }^{66}$.

İstanbul'da görev yapan ikinci DRK ekibi ise yaklaşık dört aylık sürede 381 yaralının/hastanın tedavisiyle ilgilenmişti. Bunların 360'ı silah veya şarapnel yarası nedeniyle (yaklaşık \%70’i kol ve bacak bölgesinden), geri kalan kısmı ise bıçak/kılıç yarası, ayak burkulması, taş çarpması, kolera gibi hastalıklardan şikâyetle DRK sağllk birimlerine gelmişti. Askerlerin vücutlarından çıarılan mermilere bakıldığında Bulgar askerlerinin genellikle $8 \mathrm{~mm}$ kalibreli Mannlicher marka silahlar kullandıkları tespit edilmişti. Bu silahlardan atılan mermiler isabet ettiği vücudu derinlemesine yırtıyor ve iltihaplanmaya neden oluyordu. Hastanede (Mekteb-i Sultanî) röntgen cihazı olmadığı için mermilerin bulunduğu yeri tespit edip ona göre müdahaleler gecikebiliyordu. Bu yüzden ilk günlerde gelen 26 yaralı askerden 21'i cerrahi müdahalenin ardından sağlığına kavuşmuşken 5'i kurtarılamamışt $1^{67}$.

İtalyan Okulu'ndaki (Edirne) hastanede görev yapan Dr. Teilhaber'in notlarına göre, bu birime getirilen Türk askerleri genellikle bağırsak hastalıklarından şikâyetçiydi. Askerler aylarca yetersiz beslendikleri ve temiz su içmedikleri için bünyeleri oldukça zayıflamış, bazı askerler daha tedaviye başlamadan hayatlarını kaybetmişti. Burada ağır hastalar tedavi edilmemiş, yerine göre şehirdeki Merkez Hastanesi'ne veya Hilal-i Ahmer Hastanesi'ne yönlendirilmişti. Dr. Teilhaber ve ekibinin karşılaştığı hastalıkların çoğu (mide ve bağırsak rahatsızlı̆̆ ile bronşit)

65 Liebert, "Die I. Hilfsexpedition nach Konstantinopel..”, s. 532-533.

66 Aynı yer, s. 468-536.

67 Luxembourg und Jurasz, “Die II. Hilfsexpedition nach Konstantinopel..”, s. 547-594.

Belleten, Nisan 2021, Cilt: 85/Sayı: 302; 155-191 
yeterli ve sağlıklı beslenememekten veya iklim şartlarına ve yorgunluğa bağlı olarak vücut direncinin düşmesiyle gelişen komplikasyonlar nedeniyle ortaya çıkıyordu. Neticede DRK ekibi, hastanede oluşturulan labaratuvarda hastalardan alınan numuneler sayesinde incelemeler yapmış ve tedavilerini bu istikamette yürütmüştü. Dr. Teilhaber ve diğer sağllk personelinin tedavi ettiği askerlerden sadece biri (tifüsten) hayatını kaybetmiş, diğgerleri tedavilerinin ardından taburcu edilmişlerdi68 ${ }^{6}$.

\section{Salgın Hastalıklar ve Ayastefanos (San Stefano/Yeşilköy) Karantina Merkezi}

Balkan Savaşları esnasında Osmanlı ordusunu zorlayan önemli hususlardan biri de salgın hastalıklardı. Özellikle kolera salgını Türk orudusunun içinde bulunduğu zor durumun ve problemlerin daha da kötüleşmesine neden oluyordu. Kolera ölümcül bir hastalıktı ve pensilinin olmadığı o günlerde bir ordunun savaşma kapasitesine büyük darbe vuran bir illetti. Bu hastalık, kusma ve ishal gibi etkileriyle yoğun oranda su kaybına yol açıyor ve hastalığa yakalanan askerleri savaşamayacak duruma getiriyordu. Türk tarafinda kolera salginı sadece cepheyle sınırlı kalmamış, Çatalca'daki tahkimatın gerisine hatta İstanbul'a kadar uzanmıştı. Bu feci hastalık günde neredeyse iki bin kurban alıyordu ${ }^{69}$.

Kolera ile mücadelede Sıhhiye Nezareti ve Hilal-i Ahmer Cemiyeti, İstanbul Şehremini Cemil Paşa ile işbirliği içerisinde hareket etmiş ve oluşturulan komisyonlar sayesinde hastalıkların yayılmaması için önlemler alınmıştı. Bu arada, Balkanlar'dan gelen göçmenler yaklaşmakta olan Bulgar ordusundan kaçmak suretiyle Çatalca hattının gerisine çekilirken bir biri ardına oluşturulan kolera kamplarıyla bilinçsizce temas ederek hastalığın mikrobunu az çok kapıyor ve salgını İstanbul'a kadar getiriyordu. Şehremâneti, genelgeler hazırlayarak bu şekilde gelen muhacirlerin kontrollü bir şekilde ilerlemeleri ve cami, mektep, tekke gibi alanlarda karantina altında tutulmaları için gerekli tedbirleri alıyordu ${ }^{70}$.

68 Teilhaber, "Die II. Hilfsexpedition nach Adrianopel, Beobachtungen und Tätigkeit.., s. 756-757.

69 Doruk Akyüz, "Balkan Savaşlarında Bir Siper Savaşı Örneği: Birinci Çatalca Muharebesi”, Bir Asır Sonra Balkan Savaşlar, haz. Mustafa Çalık, Cedit Neşriyat, Ankara 2015, s. 83; H.C. Seppings-Wright, age., s. 224; Alman Büyükelçisi F. von Wangenheim, Berlin’e gönderdiği 15 ve 17 Kasım 1913 tarihli raporlarında kolera salgınının Türk ordusunu epey yıprattığını ve askerler arasında moral bozukluğuna sebep olduğunu ifade etmişti. PAAA, R. 12379; R. 12380. Savaş boyunca salgın hastalıklar sadece Osmanlı ordusunu değil, Balkan müttefiki ülkeleri de olumsuz etkilemişti. Örneğin kolera salgını Bulgar ordusunu da perişan etmiş, yeterli sahra hastaneleri bulunmadığı için Bulgarlar büyük sıkıntılar yaşamıştı. Hall, age., s. 44-45.

70 Sezer-Metin, age., s. 64-65; H.C. Seppings-Wright, age., s. 225. İstanbul Şehremini Cemil Paşa'nın nezareti altında koleraya karşı alınan tedbirler hakkında bk. BOA, Dâhiliye Nezareti İdare Evrakı 
Edirne'de ise savaşın ilk aylarında kolera ve dizanteri gibi salgın hastalıklara kısmen rastlansa $^{71}$ da, kuşatma esnasında ciddi anlamda bir salgın pek görülmemişti. Bununla birlikte, halk arasında küçük bir kolera salgını nedeniyle ölenler olmuştu. Edirne'de salgın hastalıkların daha çok şehrin Bulgar kontrolüne geçmesinden sonra yayıldığı görülmüş ve bu süreçte kolera, dizanteri ve tifüsten ölenlerin sayısı artmıştı. Öyle ki, Hilal-i Ahmer Cemiyeti'nde görev yapan üç subay da koleradan hayatını kaybetmişti ${ }^{72}$.

Savaşta ilk kolera vakası Lüleburgaz Muharebelerinden yaklaşı 8-10 gün sonra görülmüştü. Cephede koleranın ortaya çlkmasıyla birlikte Harbiye Nezareti gerekli tedbirleri almaya başladı. Nezaret, bu hususta Hilal-i Ahmer Cemiyeti, Sıhhiye Nezareti ve askerî hastanelerden yardım alıyordu. Gülhane Askerî Hastanesi Başhekimi Wieting Paşa salgın hastalıklarla mücadele için bir ekip (Prof. Reich ve DRK ekibinden Dr. W. Geißler ${ }^{73}$ de ekipte yer alıyordu) teşkil ederek İstanbul yakınlarında yer alan Ayastefanos (Yeşilköy)'ta bir karantina merkezi ${ }^{74}$ oluşturmaya karar verdi. Illk olarak terk edilmiş, beş odalı bir ev temizlenerek çalışmalara başlandı. Buradaki çalışmaları DRK'den Dr. W. Geißler yönetecekti ve kendisine Misır Hilal-i Ahmer'den Dr. Ömer ile İngiliz asıllı olup Kahire'den gelen Dr. Steven; Türk doktorlar Abdülkadir Bey, Nesim Bey ve Süleyman Bey; DRK'den Anna Weidner ve Alice Zöwe; Gülhane Askerî Hastanesi'nden Hemşire Gertrud ve Bayan Schulz yardım edecekti. Zamanla daha fazla hastaya hizmet vermek için barakalar inşa edildi ve Ayastefanos Karantina Merkezi, Mısır Hilal-i Ahmer Cemiyeti’nin yardımı sayesinde çalışmalarını sürdürdü75.

(DH.iD), 164/1, 24 Teşrinievvel 328/6 Kasım 1912.

71 Savaşın ilk aylarında, çok yaygın olmasa da, Edirne'de kolera salgını olmuş ancak, alınan tedbirler sayesinde 1913 yılının başlarında hastalık kontrol altına alınmıştı. BOA, Dâhiliye Nezareti Şifre Kalemi (DH.ŞFR), 419/56, 29 Kanunuevvel 1328/11 Ocak 1913.

72 Hildebrandt, "Die I. Hilfsexpedition nach Adrianopel..”, s. 715.

73 Dreyer, "Die III. Hilfsexpedition nach Konstantinopel..", s. 599.

74 Hilal-i Ahmer Cemiyeti'nin Ayasefanos'ta bir hastanesi vardı ve kurulacak karantina merkezi bu hastaneyle işbirliği içerisinde faaliyet yürütecekti. BOA, DH.ID, 47/16, 27 Cemaziyelevvel 1331/4 Mayis 1913.

75 Mısır Hilal-i Ahmer Cemiyeti, Karantina Merkezi'ne yatakların dışında battaniye, palto, uzun bot, lastik çizme, lastik palto gibi burada gerekli olan malzemeleri de göndermişti. W. Geißler, "Die III. Hilfsexpedition nach Konstantinopel, Die Colerabekämpfung in San Stefano", Beiträge zur Kriegsheilkunde, Aus den Hilfsunternehmung der Deutschen Vereine vom Roten Kreuz Während des ItalienischTürkischen Feldzuges 1912 und des Balkankriegs 1912-13, Hrsg: Central-Komitee der Deutschen Vereine vom Roten Kreuz, Springer Verlag, Berlin 1914, s. 633-635, 645. 


\section{Alman Salib-i Ahmer (Kızılhaç) Cemiyeti'nin İstanbul ve Edirne'de Yürüttüğü Sağlık Çalışmaları}

Karantina Merkezi'nde her şeyden önce çalışmaların amacına uygun olarak büyük bir laboratuvar oluşturuldu. Düzen kurulduktan sonra planlama şu şekilde yapıldı: Kolera, dizanteri ve tifüs vakalarının öncelikle bakteriyolojik tespiti yapılacak ve hastalar ayrı ayrı bölümlerde tedavi altına alınacaktı. Wieting Paşa sık sık buraya ziyarete gelerek çalışmaları yakından takip ediyordu ${ }^{76}$. Faaliyete başladığı ilk günlerde Karantina Merkezi'ne Çatalca'dan gelen trenler binlerce yaral, hasta ve hayatını kaybetmiş asker getiriyordu. Şehit sayısı o kadar çoktu ki, bunların defnedilmesi için 40-60 kişilik toplu mezarlar açllyordu. Ayastefanos Karantina Merkezi'nde her biri 120 yatak alan altı büyük baraka, bir laboratuvar ${ }^{77}$, bir eczane, ölenler için bir oda ve bir depo (yatak, saman, fener, su 1sitıcısı gibi malzemelerin konulduğu) yer alıyordu. Her baraka (ahşap) iki büyük veya dört küçük odaya bölünebiliyordu. Yine her barakada nöbetçi doktor için bir oda, küçük bir depo (ekmek, su, ilaç vs. için), hemşireler için bir oda ve mutfak eşyaları ile sedyeler için de ayrı bir oda bulunuyordu ${ }^{78}$.

Hâlihazırda, yani salgının ortaya çıkmasıyla birlikte, cephede izolasyon mümkün olmadığı için yapılacak en uygun hareket bu hastaların demiryolu ile acilen İstanbul'a nakledilmesiydi.

Hastalar trenlerle taşınıyordu ancak, ordunun düşman karşısında aldığı yenilgiler ve düzensiz ricatı nedeniyle hastalarla sağlam askerler birbiriyle temas ediyor, bu da kolerayla mücadeleyi zorlaş̧ırıyordu. Neticede Çatalca'ya kadar çekilen Türk askerlerinin bir kısmı açlık ve yorgunlukla mücadele ederken, büyük bir kısmı da başta kolera olmak üzere dizanteri ve tifüs gibi bulaşıcı hastalıkların pençesinde hayat mücadelesi veriyordu. Askerler yeterince beslenemiyor, bazen günlerce aç kaldıkları için fiziksel olarak dirençleri kırılıyordu ${ }^{79}$.

Diğer taraftan, Lüleburgaz Muharebeleri'ne kadar Bulgar ordusunda kolera salgını görülmemişken, Türk ordusunun çekildiği yerlerdeki su kaynaklarından faydalanmaya başlayan Bulgar askerleri arasında da kolera vakası görülmeye

76 Wieting Paşa'ya bu ziyaretleri esnasında Sahra Sıhhiye Müfettişi Emin Paşa ile Hilal-i Ahmer Cemiyeti ve Daire-i Sıhhiye-i Askeriye'den birer doktor eşlik ediyordu. BOA, BEO, 4120/308941, 24 Zilhicce 1330/4 Aralik 1912.

77 Geißler, “Die III. Hilfsexpedition nach Konstantinopel..”, s. 650.

78 Wieting Paşa, Osmanlı ordusunda görülen kolera vakasının ilk olarak Suriye'den gelen birlikler arasında ortaya çıktığını tespit etmiştir. Geißler, "Die III. Hilfsexpedition nach Konstantinopel..", s. 637-644; Luxembourg und Jurasz, "Die II. Hilfsexpedition nach Konstantinopel..”, s. 540.

79 Geißler, “Die III. Hilfsexpedition nach Konstantinopel..”, s. 638-639. 
başlandı. Aslında Bulgarlar, hızlı bir şekilde ilerleyip İstanbul'u ele geçirmeyi planlamıştı. Oysa hiç hesapta olmayan kolera salgını nedeniyle Bulgar ordusunun saldırı gücü zayıflamış ve Bulgarlar, Türk askerinin Çatalca'daki şiddetli savunması karşısında, bu salgının da etkisiyle durmak zorunda kalmıştı. Neticede imzalanan ateşkes, orduların yeniden hazır hale gelebilmeleri için her iki tarafa gerekli zaman aralığını kazandırmıştı ${ }^{80}$.

Salgınının orduda yayılmasıyla birlikte İstanbul'a çok sayıda koleraya yakalanmış asker getirilmeye başlandı. Şehremini Cemil Paşa bu askerlerin büyük camilerde tedavi altına alınması için gerekli çalışmaları yapmıştı. Başta Ayasofya olmak üzere Sultan Ahmed ve diğer pek çok cami, bu şekilde gelen askerlerin (yaklaşık 6 bin asker) tedavisi için tahsis edildi ${ }^{81}$.

İstanbul'da ve salgın hastalıkların yayıldığı diğer bölgelerde, Uluslararası Sağlık Konseyi'nin kararları doğrultusunda, sıkı bir dezenfekte çalışması başlatıldı. Bu, salgınla mücadelede ${ }^{82}$ çalışmaların en kapsamlı ve maliyetli kısmını oluşturuyordu. Başta demiryolu istasyonları olmak üzere, vagonlar, camiler ve hatta cesetler bile dezenfekte ediliyordu. Hayatını kaybeden askerlerin defnedilmesi için Edirnekapı ve Üsküdar taraflarında uygun araziler belirlendi ${ }^{83}$.

Karantina Merkezi’nde DRK sağlık ekibi yüzlerce hastanın tedavisiyle ilgilenmiş ve Dr. W. Geißler hastalarla ilgili bir istatistik dahi hazırlamıştı. Alman ekibinin buradaki laboratuvarda yaptığı tahlillere dair detaylı bilgi şu şekildeydi:

Karantina Merkezi'ne gelen 1030 hastanın 349'una bir hastalık tanısı konulmuştu. Bu hastalardan \%45 (157)’i kolera, \%41,3 (144)'ü dizanteri, \%7,7 (27)'si tifüs, \%4 (14)'ü tüberküloz ve \%2 (7)'si ise vidal kan reaksiyonu teşhisiyle

80 Geißler, "Die III. Hilfsexpedition nach Konstantinopel..”, s. 639. PAAA, R. 12466, 30 November 1912.

81 Sabis, age., s. 70. Alman Büyükelçisi F. von Wangenheim Berlin’e gönderdiği 7 Kasım 1912 tarihli mektubunda, İstanbul'daki pek çok caminin cepheden getirilen yaralıların tedavisi için Hilal-i Ahmer Cemiyeti'ne tahsis edildiğini belirtmiştir. PAAA, R. 12364, 7 November 1913.

82 DRK, salgınla mücadele ederken Osmanlı Halil-i Ahmer Cemiyeti ve Harbiye Nezareti’nin dışında Avusturya Kızılhaç'ı (Österreichischen Roten Kreuz) ve Danimarka Kızılhaç'ı (Dänische Rote Kreuz) ile de işbirliği yapmıştı. Diğer yandan cephelerde seyyar salgın laboratuvarları (der mobilen Epidemielaboratorien) oluşturmak suretiyle hasta askerlere daha erken müdahale etme olanağı bulmuştu. Kimmle, "Die Hilfsexpeditionen des Deutschen Roten Kreuzes...”, s. 22.

83 Bunun için dezenfektanların yanında klor (bakteri öldürücü), formalin (dokuları çürütmeden, bozmadan saklayabilmek için kulanılan bir sıvı olup aynı zamanda mantar, bakteri ve parazit vs. üremesini de engellemektedir) ve kireç kullanıldı. Bazı binaların dış cepheleri de dezenfekte edildi. Geißler, "Die III. Hilfsexpedition nach Konstantinopel...", s. 641. 
tedavi altına alınmıştı. Bununla birlikte, askerlerden alınan numuneler üzerinden yapılan tahliller neticesinde birden fazla hastalığa yakalanan asker sayısı 391 idi. Bunlar içerisinde kolera ve dizanteriye birden yakalananların sayısı $302(\% 77)$; kolera, dizanteri ve tifüse birden yakalananların sayısı 56 (\%14); kolera, tifüs ve tüberküloza birden yakalananların sayısı $19(\% 5)$; kolera, dizanteri, tifüs ve vidal kan reaksiyonu tanısı konulanların sayısı ise $14(\% 4)$ idi $^{84}$.

\section{5. Çalışmaların Sona Ermesi ve DRK Ekiplerinin Almanya'ya Dönüşü}

Balkan Savaşları esnasında Osmanlı topraklarında görev yapan DRK personelinin hizmet ettikleri süre zarfinda gerek Osmanlı ve Mısır Hilal-i Ahmer Cemiyeti çalışanlarıyla, gerekse Harbiye ve Sıhhiye Nezaretleri'ne mensup sağlık personeliyle büyük bir uyum içerisinde çalıştıları görülmüş; görevleri sona erdikten sonra Berlin'e dönerken de Almanya'dan beraberlerinde getirdikleri sağlık malzemelerinin bir kısmını Türk meslektaşlarına bırakmışlardı ${ }^{85}$.

28 Ekim 1912'de İstanbul'a gelen ilk DRK ekibi Gümüşsuyu Askerî Hastanesi’nde yürüttüğü sağlık çalışmalarını 13 Mayıs 1913 tarihinde sonlandırmış ve Berlin'e dönmüştü. Aslında ekipteki çalışanlardan bazıları (Anny Mayer, Maria Stegmayer ve Leonhard Dorsch) hastalık nedeniyle daha evvel Almanya'ya dönmek zorunda kalmışlardı $^{86} .4$ Kasım 1912'de İstanbul'a gelen ikinci DRK ekibi ise önce Mekteb-i Sultanî’de, daha sonra İstanbul Baytar Mektebi'nde oluşturulan sağllk birimlerinde hizmet etmiş, yaklaşık 4,5 aylık çalışmanın ardından 13 Mart 1913 tarihinde Almanya'ya geri dönmüştü ${ }^{87} .25$ Kasım 1912'de İstanbul'a gelen üçüncü DRK ekibi yaklaşık altı ay Osmanlı topraklarında kalmış, 16 Mayıs 1913 tarihine kadar önce Beylerbeyi Hastanesi'nde, daha sonra Vefa Mektebi’nde oluşturulan hastanede çalışma yürütmüştü ${ }^{88}$.

84 Geißler, “Die III. Hilfsexpedition nach Konstantinopel..”, s. 650-652.

85 Osmanlı hükûmeti, savaş esnasında DRK sağlık personelinin özverili çalışmalarını dikkate alarak başta Alman doktorlar olmak üzere, hemşire ve hastabakıcıların neredeyse tamamını hizmetlerine göre 3. ve 4. rütbeden mecidiye veya şefkat ve liyakat nişanları ile taltif etmiştir. BOA, İrade Taltifat (İ.TAL), 483/16, 1 Mayıs 1329/14 Mayıs 1913; İ..TAL, 483/29, 22 Mays 1329/4 Haziran 1913; 483/16, 5 Cemaziyelahir 1331/12 Mayıs 1913.

86 Liebert, "Die I. Hilfsexpedition nach Konstantinopel..”, s. 466.

87 Luxembourg und Jurasz, "Die II. Hilfsexpedition nach Konstantinopel..”, s. 547.

88 Kimmle, agm., s. 15. Üçüncü DRK ekibi ilk üç ay Beylerbeyi’nde görev yapmış, yaklaşık 1,5 ay ise Vefa Mektebi'nde çalışmalarını sürdürmüştür. Dreyer, "Die III. Hilfsexpedition nach Konstantinopel..”, s. 605. Görüldüğü gibi, birinci ve üçüncü DRK ekibi hemen hemen aynı 
Edirne'ye gelecek ilk DRK sağlık ekibinin Berlin'den 22 Kasım'da hareket etmesine rağmen Bulgar makamlarının engellemeleri nedeniyle şehirde tam anlamıla çalışmalara başlaması Mart (1913) ayının sonlarını bulmuştur. Alman ekibinin gelişi Edirne'nin Bulgar işgali dönemine denk geldiğinden sağlı çalışmaları oldukça zor şartlarda devam etmiş, yine de şehirde kaldıkları süre boyunca Merkez Hastanesi ile Hilal-i Ahmer Hastanesi'ne malzeme tedarikinde önemli hizmetleri olmuştu. DRK ekibi, ellerinde yeterli malzeme kalmadığı ve bu halde şehirde kendilerine ihtiyaç bulunmadığı yönünde Berlin'e gönderdikleri rapor üzerine Merkez Komitesi'nin emriyle 9 Nisan 1913 tarihinde Almanya'ya dönmüştür ${ }^{89}$.

Illk ekibin Almanya'ya döneceği günlerde, DRK Merkez Komitesi Bulgarlar tarafından esir alınan yaralı ve hasta Türk askerlerinin bakımı için 8 Nisan 1913 tarihinde Edirne'ye yeni bir ekip daha gönderme kararı aldı ve DRK sağlık ekibi 12 Nisan'da Sofya'ya gelmesine rağmen ekibin Edirne'ye ulaşması 15 Nisan'ı buldu. Dr. Kirschner ve Dr. Teilhaber yaralı ve hasta Türk esirlerinin tedavileriyle özverili bir şekilde ilgilenmişler ve DRK Merkez Komitesi'nin emriyle 22 Mayıs 1913 tarihinde çalışmalarını tamamlayarak Edirne'den ayrılmışlard ${ }^{90}$.

Alman sağlık ekiplerinin Osmanlı topraklarını terk etmesinden kısa bir süre sonra büyük devletlerin araya girmesiyle, 30 Mayıs 1913'te Londra Barış Antlaşması ile savaş sona erdi. Buna göre, Midye-Enez Hattı Osmanlı-Bulgar sınırı olarak kabul edildi. Edirne, Trakya ve Dedeağaç Bulgaristan'a; Selanik, Güney Makedonya ve Girit Yunanistan'a; Kuzey ve Orta Makedonya Sirbistan'a; Silistre de Romanya'ya bırakıldı. Ancak, Balkan müttefiki ülkeler Osmanlı Devleti'nden aldıkları toprakları paylaşma hususunda uyuşmazlığa düşerek birbirlerine karşı mücadeleye giriştiler. Bu mücadeleye Birinci Balkan Savaşı'nda yer almayan Romanya da dâhil oldu ve böylece İkinci Balkan Savaşı başladı. Savaşta Bulgaristan bütün cephelerde yenilmeye başlayınca Osmanlı kuvvetleri 21 Temmuz'da Trakya ve Edirne'yi Bulgarlar'dan geri almayı başardı. İkinci Balkan Savaşı 10 Ağustos 1913'te Bulgaristan'la Sırbistan, Yunanistan ve Karadağ arasında imzalanan Bükreş Antlaşması'yla sona erdi. İngiltere Dışişleri Bakanı Sir Edward Grey, Osmanlı'ya aldığı yerleri boşaltma tavsiyesinde bulunduysa da Türk tarafı bunu dikkate

günlerde Almanya'ya dönmüşlerdi. İstanbul'da bu ekiplere daha ihtiyaç olmasına rağmen bunların birbiri ardına Berlin'e dönmelerinin en önemli sebebi savaşın uzun sürmesi nedeniyle ellerinde yeterli malzemenin kalmamasiydı. BOA, BEO, 4157/311758.

89 Hildebrandt, "Die I. Hilfsexpedition nach Adrianopel..", s. 723.

90 Kirschner, "Die II. Hilfsexpedition nach Adrianopel..”, s. 753. 
almamış ve nihayet Osmanlı-Bulgar Antlaşması (İstanbul Antlaşması) da 29 Eylül 1913 'te imzalanmışıı ${ }^{91}$. Osmanlı Devleti Balkan Savaşları'nda yaklaşık 340.000 kayıp vermişti. Ayrıca, yenilgiyle birlikte Balkanlar'dan Anadolu'ya doğru kitlesel bir muhâcir göçü başlamış ve bu süreçte Anadolu'ya gelen neredeyse 400.000 Müslüman, Anadolu coğrafyasının nüfus yapısında büyük değişikliklere neden olmuştur ${ }^{92}$.

\section{Sonuç}

Cenevre Sözleşmesi (1864)'yle başlayan ve yaralı askerlerin masuniyeti anlayışına bağlı olarak savaşlarda yaralanan veya hasta olan askerlerin din ve milliyetine bakılmaksızın uluslararası Kızılay/Kızılhaç kuruluşlarınca tedavi edilmesi geleneği, Balkan Savaşları'nda en güzel şekliyle uygulanmış; Alman Kızılhaçı’nın gönderdiği beş sağllk ekibi İstanbul ve Edirne'de Türk sağllk personeliyle büyük bir uyum içerisinde başarılı çalışmalar yürütmüştü. Trablusgarp Savaşı (191112)'nda olduğu gibi Balkan Savaşları esnasında da cephe gerisinde Türk ve Alman sağlık personeli cepheden gelen yaralı ve hasta Türk askerlerine birlikte müdahale etmişlerdi.

Alman sağlık ekipleri, İstanbul ve Edirne'de görev yaptıkları süre içerisinde silah teknolojisinde meydana gelen gelişmelerin etkisiyle mermi ve topların askerlerin vücutlarında ağır tahribata sebep olması ve diğer yandan iklim koşullarına ek olarak Osmanlı ordusundaki aksaklıklardan dolayı Türk askerleri arasında görülen kangren ve salgın hastalık vakasının yüksek olması nedeniyle oldukça zorlu bir çalısma yürütmüşler ve görev yaptıkları süre içerisinde binlerce Türk askerinin sağlığına kavuşması için gayret sarf etmişlerdi. Harbiye Nezareti ve Hilal-i Ahmer Cemiyeti sağlık personelinin cepheden çok sayıda yaralı ve hasta asker geldiği zamanlarda Alman doktor, hemşire ve hastabakıcıların destekleri sayesinde kimi zaman yükleri hafiflemiş, kimi zaman da her iki taraf yaralılara birlikte müdahale ederek tecrübelerini birbirlerine aktarmıslardı. Alman sağlık personeli İstanbul ve Edirne'de çalışrken iletişim, beslenme ve diğer bazı hususlarda sorunlar yaşasa da önceliği yaralı ve hasta askerlerin tedavisine verdiklerinden genel anlamda başarılı bir çalışma yürüttükleri söylenebilir.

91 Küçük, agm., s. 24; Troçki, Balkan Savaşlan, s. 500-501.

92 Edward J. Erickson, Defeat in Detail: Ottoman Army Operations in the Balkans, 1912-1913, Westport, Connecticut: Praeger, London 2003, s. 329; Beşikçi, agm., s. 73. 
Osmanlı Devleti'nin Balkan Savaşları'nı kaybetmesinin nedenleriyle ilgili olarak Alman Salib-i Ahmer Cemiyeti personelinin raporlarında belirttiği ve bu savaşı değerlendiren yerli ve yabancı kaynakların da desteklediği görüşe göre, Balkan Savaşları'nda Türk ordusu cephede düşman askerle çarpışarak değil hastalık, yetersiz beslenme ve kış şartlarıyla mücadele edememe gibi sorunlar yüzünden fazla kayıp vermişti. Diğer bir ifadeyle, kayıpların çoğu cephedeki mücadeleden değil, cephe gerisindeki sorunlardan kaynaklanıyordu ki, Batılı gözlemcilerin ifadesiyle, Türk askerinin Balkan Savaşları esnasında sahip olduğu şartlar (açlık, mühimmat eksikliği, yorgunluk vb.) herhangi bir Batılı orduda bulunsaydı, muhtemelen bu askerlerin büyük bir kısmı savaşın daha ilk gününden itibaren cepheyi terkederdi. $\mathrm{Bu}$ şekilde, olumsuz şartlara rağmen mücadeleye devam eden Türk askerinin metânetli ve mütevekkil yapısını yakından görme imkânı bulan Alman sağlık çalışanları, savaşın ilk günlerinden itibaren Türk sağlık personeline büyük destek vermiş ve görevlerini tamamlayıp Almanya'ya dönerken de beraberlerinde getirdikleri malzemelerin (cerrahi müdahale ekipmanı, röntgen vs.) büyük bir kısmını Osmanlı-Alman dostluğunun nişânesi olarak Türk meslektaşlarına bırakmışlardı. Nihayetinde, diğer savaşlardaki kısmî yardımlar istisna edilecek olursa, Alman Salib-i Ahmer Cemiyeti'nin Trablusgarp ve Balkan Savaşları esnasında ortaya koyduğu bu dostane destek, Birinci Dünya Savaşı'nda OsmanlıAlman ittifakının da etkisiyle yine devam edecek ve DRK, savaş yıllarında tekrar Osmanlı topraklarına sağlık ekipleri gönderecektir. 


\section{KAYNAKLAR}

\section{Arşiv Kaynakları}

Cumhurbaşkanlığı, Devlet Arşivleri Başkanlığı, Osmanlı Arşivi (BOA)

Bâb-1 Ali Evrak Odası (BEO), 4100/307451; 4104/307794; 4120/308941; 4120/308994; 4123/309205; 4157/311758; 4180/313467; 4183/313678.

Dâhiliye Nezareti İdare Evrakı (DH.ID), 47/16; 164/1.

Dâhiliye Nezareti Siyasi Kısım Evrakı (DH.SYS), 112/7.

Dâhiliye Nezareti Şifre Kalemi (DH.ŞFR), 419/56.

Hariciye Nezareti Londra Sefareti (HR.SFR.3..), 664/60; 692/21.

Hariciye Nezareti Siyasi Kısım Evrakı (HR.SYS), 112/7; 2025//4; 2025/5; 2026/1.

İrade Taltifat (İ..TAL), 483/16; 483/29; 483/16.

Maarif Nezareti Mektubi Kalemi (MF.MKT), 1182/43; 1182/79.

Meclis-i Vükelâ Mazbataları (MV), 177/104.

Kızılay Arşivi (KA)

18/52; 94/28; 94/35; 256/100.

\section{Politisches Arschiv des Auswärtigen Amtes Berlin-PAAA (Alman Dışişleri Bakanlığı Siyasal Arşivi)}

R. 12364; 12378; 12379; 12380; 12466; 12476; 12479; 12493.

\section{Araştırma, İnceleme Eserler ve Raporlar}

Akgün Karal, Seçil - Murat Uluğtekin, Hilal-i Ahmer'den Kizılay'a, Ankara 2002.

Akyüz, Doruk, "Balkan Savaşlarında Bir Siper Savaşı Örneği: Birinci Çatalca Muharebesi", Bir Asır Sonra Balkan Savaşlan, haz. Mustafa Çalık, Cedit Neşriyat, Ankara 2015, s. 75-91.

Andonyan, Aram, Balkan Harbi Tarihi, çev. Zaven Biberyan, Sander Yayınları, İstanbul 1975.

Bayur, Yusuf Hikmet, Türk İknlabı Tarihi, C II/Kısım 2, Türk Tarih Kurumu Yayınları, Ankara 1983.

Beşikçi, Mehmet, "Balkan Harbi’nde Osmanlı Seferberliği ve Redif Teşkilatının İflası", Bir Asır Sonra Balkan Savaşları, haz. Mustafa Çalık, Cedit Neşriyat, Ankara 2015, s. 45-74. 
Çapa, Mesut, "Balkan Savaşı'nda Kızılay (Osmanlı Hilâl-i Ahmer Cemiyeti)", Ankara Üniversitesi Osmanl Tarihi Araştırma ve Uygulama Merkezi Dergisi (OTAM), S. 1, Ankara 1990, s. 89-115.

Dağlar, Oya, "Balkan Savaşları’nda İnsancıl Hukuk İhlallerine İki Örnek Olay: Alman Kızılhaç Ekiplerinin Karşılaştıkları Engeller ve Mısır Kızılay Vapuruna El Konması", Galatasaray Üniversitesi Hukuk Fakültesi Dergisi, S. 2, 2007, s. 235-257.

Dinçer, Serdar, Birinci Dünya Savaşı'nın 100. Yilında Alman Dışişleri Belgelerinde Krupp’un Bitmeyen Balkan Savaşı, Sürgün ve Soykımm, Favori Yayınları, Ankara 2014.

Dreyer, Lothar (Dr.), "Die III. Hilfsexpedition nach Konstantinopel, Chirurgische Beobachtungen in dem Lazarett des Ägyptischen Roten Halbmonds in Beylerbey und in dem Lazarett in Stambul", Beiträge zur Kriegsheilkunde, Aus den Hilfsunternehmung der Deutschen Vereine vom Roten Kreuz Während des ItalienischTürkischen Feldzuges 1912 und des Balkankriegs 1912-13, Hrsg: Central-Komitee der Deutschen Vereine vom Roten Kreuz, Springer Verlag, Berlin 1914, s. 596-633.

Erickson, Edward J., Defeat in Detail: Ottoman Army Operations in the Balkans, 19121913, Westport, Connecticut: Praeger, London 2003.

Frik, Feridun, "Alman Kızılhaçının Trablus ve Balkan Harplerindeki Sıhhi Yardım Hizmetleri Eserinden Memleketimize Ait Notlar”, Dirim, 30/8, Ağustos 1955, s. 344-351.

Frik, Feridun, "Alman Kızılhaçının Trablus ve Balkan Harplerindeki Sıhhi Yardım Hizmetleri Eserinden Memleketimize Ait Notlar”, Dirim, 30/9, Eylül 1955, S. 388-392.

Geißler, W. (Dr.), "Die III. Hilfsexpedition nach Konstantinopel, Die Colerabekämpfung in San Stefano", Beiträge zur Kriegsheilkunde, Aus den Hilfsunternehmung der Deutschen Vereine vom Roten Kreuz Während des ItalienischTürkischen Feldzuges 1912 und des Balkankriegs 1912-13, Hrsg: Central-Komitee der Deutschen Vereine vom Roten Kreuz, Springer Verlag, Berlin 1914, s. 633-660.

Göksoy, Ertuğrul, "Alman Profesör Kirschner'in 1912-1913 Balkan Harbi Sırasında Edirne'deki Gözlemleri”, 38. Uluslararası Tip Tarihi Kongresi Bildiri Kitabı, ed. N. Sarı - A. H. Bayat - Y. Ülman - M. Işın, XXVI/146, G III, s. 1453-1456. 
Hall, Richard G., Balkan Savaşlan 1912-1913 I. Dünya Savaşı’nın Provası, çev. M. Tanju Akad, Homer Kitabevi, İstanbul 2003.

Hildebrandt, A. (Dr.), "Die I. Hilfsexpedition nach Adrianopel", Beiträge zur Kriegsheilkunde, Aus den Hilfsunternehmung der Deutschen Vereine vom Roten Kreuz Während des Italienisch-Türkischen Feldzuges 1912 und des Balkankriegs 1912-13, Hrsg: Central-Komitee der Deutschen Vereine vom Roten Kreuz, Springer Verlag, Berlin 1914, s. 661-681 ve 761-743.

Kimmle (Dr.), "Die Hilfsexpeditionen des Deutschen Roten Kreuzes nach Tripolitanen (1912) und nach dem Balkan (1912-1913)", Beiträge zur Kriegsheilkunde, Aus den Hilfsunternehmung der Deutschen Vereine vom Roten Kreuz Während des Italienisch-Türkischen Feldzuges 1912 und des Balkankriegs 1912-13, Hrsg: Central-Komitee der Deutschen Vereine vom Roten Kreuz, Springer Verlag, Berlin 1914, s. 12-31.

Kirschner (Dr.), "Die II. Hilfsexpedition nach Adrianopel, Chirurgische und sonstige Beobachtungen in Adrianopel", Beiträge zur Kriegsheilkunde, Aus den Hilfsunternehmung der Deutschen Vereine vom Roten Kreuz Während des ItalienischTürkischen Feldzuges 1912 und des Balkankriegs 1912-13, Hrsg: Central-Komitee der Deutschen Vereine vom Roten Kreuz, Springer Verlag, Berlin 1914, s. 744-754.

Küçük, Gevdet, "Balkan Savaşı", TDV İlam Ansiklopedisi, G 5, İstanbul 1992, s. 23-25.

Liebert (Dr.), "Die I. Hilfsexpedition nach Konstantinopel", Beiträge zur Kriegsheilkunde, Aus den Hilfsunternehmung der Deutschen Vereine vom Roten Kreuz Während des Italienisch-Türkischen Feldzuges 1912 und des Balkankriegs 1912-13, Hrsg: Central-Komitee der Deutschen Vereine vom Roten Kreuz, Springer Verlag, Berlin 1914, s. 455-537.

Luxembourg, Heinrich - Anton Jurasz, "Die II. Hilfsexpedition nach Konstantinopel", Beiträge zur Kriegsheilkunde, Aus den Hilfsunternehmung der Deutschen Vereine vom Roten Kreuz Während des Italienisch-Türkischen Feldzuges 1912 und des Balkankriegs 1912-13, Hrsg: Central-Komitee der Deutschen Vereine vom Roten Kreuz, Springer Verlag, Berlin 1914, s. 537-596.

Osman Nuri (Yüzbaşı), Balkan Harbi Hatıratı, haz: Zeynep Kerman, Dergâh Yayınları, İstanbul 2014. 
Öztuna, Yllmaz, Büyük Türkiye Tarihi, C 7, Ötüken Neşriyat, İstanbul 1978, s. 263278.

Padişah'ın Himayesinde Osmanh Kizılay Cemiyeti 1911-1913 Yillı̆̆ı, haz. A. Zeki İzgöerRamazan Tuğ, Türkiye Kızılay Derneği, Ankara 2013.

Rıfkı, Ragıb, Balkan Hukûmetlerinin Teşkilât-ı Askeriyesi (Romanya, Bulgaristan, Sirbistan, Yunanistan, Karadağ Ordularnna Dair Yeni ve Son Malumatı Havidir), Şems Matbaası, Dersaadet H.1328/R.1330.

Sabis, Ali İhsan, Balkan Savaşı'nda Neden Bozguna Uğradık, Balkan Savaşı’nda Askerî Yenilgimizin Sebepleri, Alfa Yayınları, İstanbul 2012.

Seppings-Wright, H. C., Trablusgarp ve Balkan Savaşlarnda Hilal Altında İki Yul, çev. Derin Türkömer, Türkiye İş Bankası Kültür Yay., İstanbul 2013.

Sezer, Cemal - Metin, Ömer Hilal-i Ahmer Cemiyetinnin Balkan Savaşlarnda Muhacirlere Yardımlar, Ankara 2016.

Şimşek, Muttalip, “Trablusgarp Savaşı'nda Alman Kızılhaç (Salib-i Ahmer) Cemiyeti’nin Çalışmaları, Atatürk Araştırma Merkezi Dergisi, G. XXXV, Güz 2019, S. 100, s. 325-352.

Teilhaber, Felix, "Die II. Hilfsexpedition nach Adrianopel, Beobachtungen und Tätigkeit auf dem Gebiete der Inneren Medizin", Beiträge zur Kriegsheilkunde, Aus den Hilfsunternehmung der Deutschen Vereine vom Roten Kreuz Während des Italienisch-Türkischen Feldzuges 1912 und des Balkankriegs 1912-13, Hrsg: CentralKomitee der Deutschen Vereine vom Roten Kreuz, Springer Verlag, Berlin 1914, s. 754-759.

Troçki, Lev, Balkan Savaşlan, çev. Tansel Güney, Türkiye İş Bankası Kültür Yayınları, İstanbul 2019.

Trotzki, Leo, Die Balkankriege 1912-13, Übersetzt (Aus dem Russisch): Hannelore Georgi und Harald Schbärth, Arbeiterpresse Verlag, Essen 1995.

Türk, Fahri, Türkiye ile Almanya Arasindaki Silah Ticareti (1871-1914), IQ Kültür Sanat Yayıncllı, İstanbul 2012.

Yıldırım, Nuran, Savaşlardan Modern Hastanelere Türkiye'de Hemşirelik Tarihi, Vehbi Koç Vakfi, İstanbul 2014. 
Alman Salib-i Ahmer (Kızlhaç) Cemiyeti’nin İstanbul ve Edirne'de Yürüttüğü Sağlık Çalışmaları

\section{EKLER}

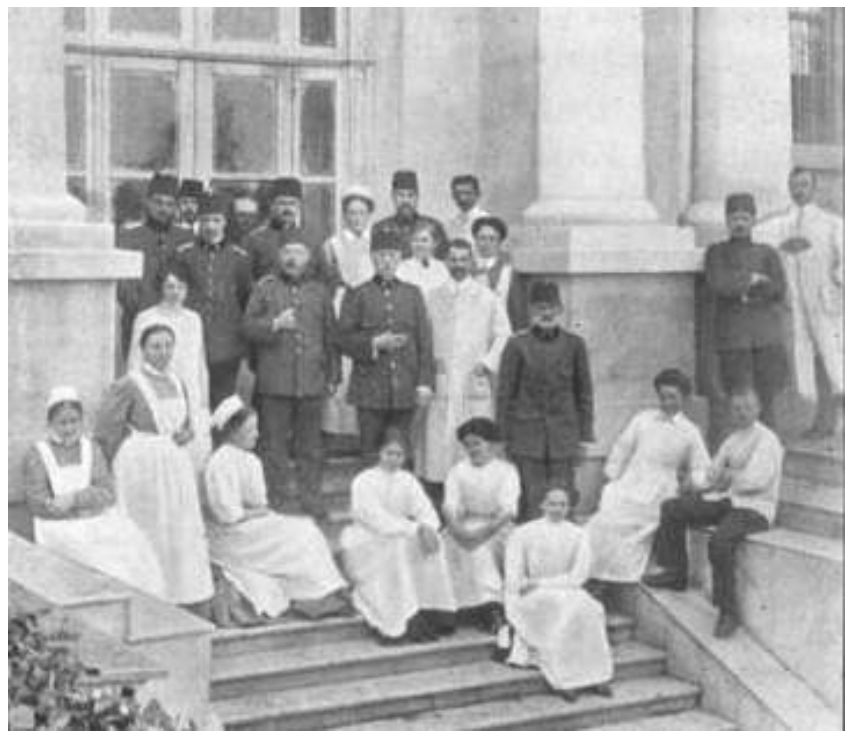

Ek 1: Gümüşsuyu Askerî Hastanesi'nde görev yapan Türk ve Alman (DRK) sağlık personeli.

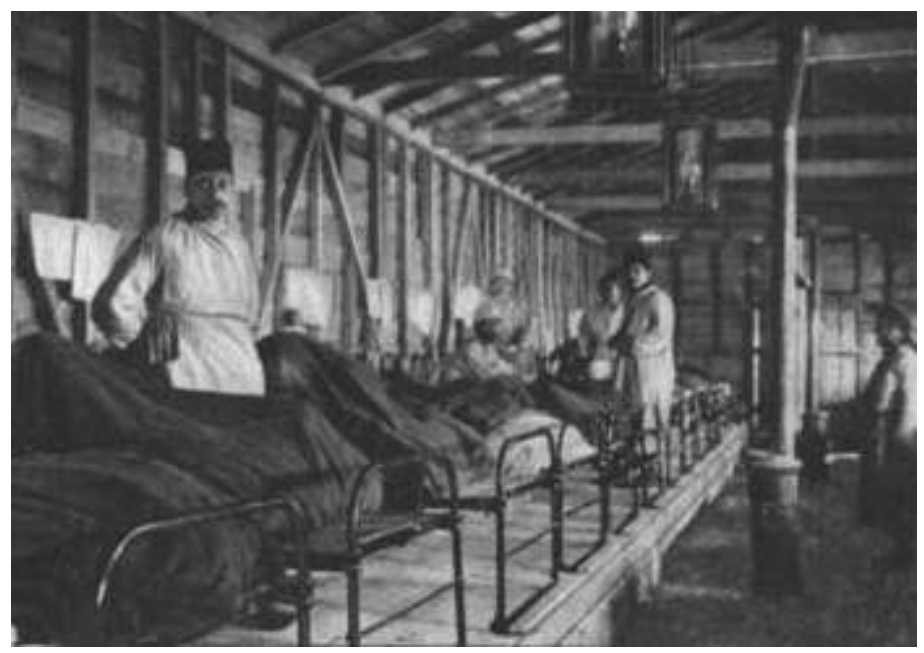

Ek 2: Ayastefanos (Yeşilköy) Karantina Merkezi, Kolera Barakası. 


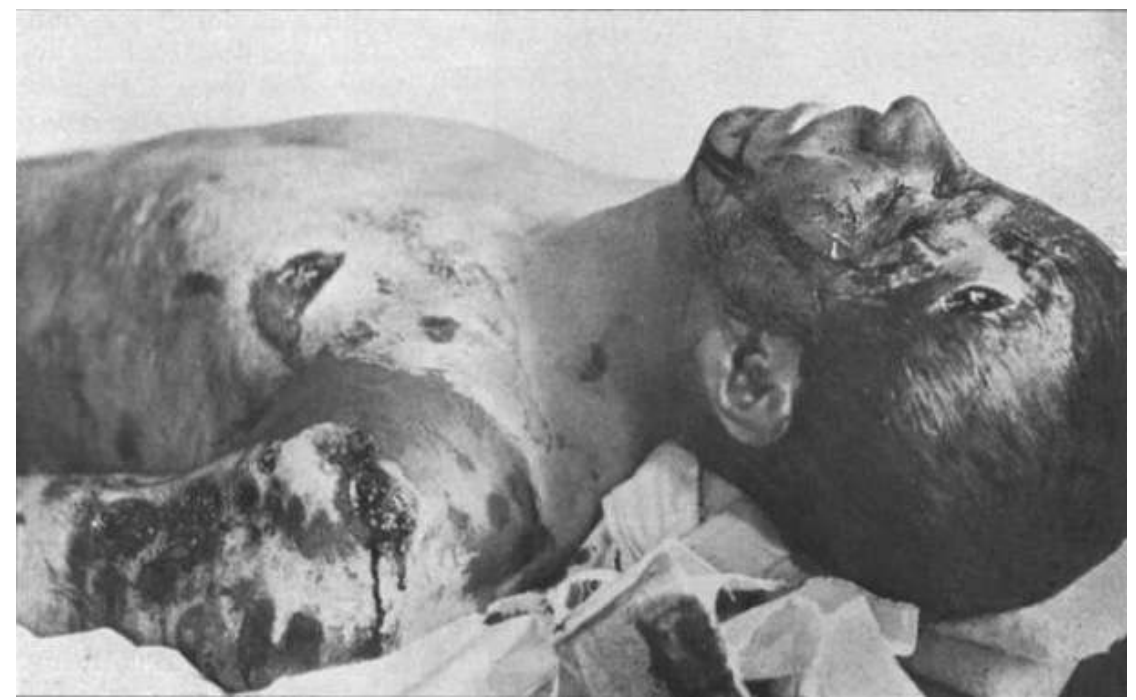

Ek 3: 18 Kasım 1912'de yedi şarapnel parçasıyla yaralanan bu Türk askeri, zahmetli bir yolculuktan sonra İstanbul'daki hastaneye getirildi ve DRK sağlık ekibi tarafindan tedavi altına alındı. İyileşmesi neredeyse iki ayı buldu ve Ocak (1913) ayının ortalarında taburcu oldu. 

Alman Salib-i Ahmer (Kızılhaç) Cemiyeti’nin İstanbul ve Edirne’de
Yürüttüğü Sağlık Çalışmaları

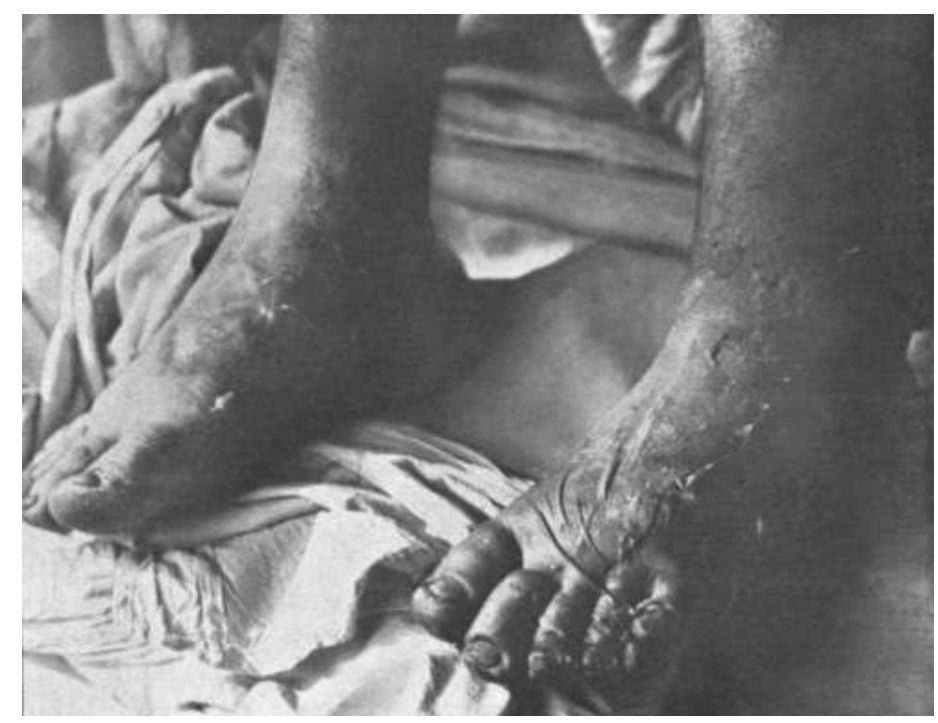

Ek 4: 22 Aralık 1912'de hastaneye getirilen Türk askerinin her iki ayağı da kangren olmuştu. Beslenme yetersizliği de olan ve hastaneye oldukça bitkin bir vaziyette gelen bu Türk askeri tedavi altına alınmışsa da ne yazık ki, aynı gün hayatını kaybetmişti.

Kaynak (Ek 1-4): Beiträge zur Kriegsheilkunde, Aus den Hilfsunternehmung der Deutschen Vereine vom Roten Kreuz Während des Italienisch-Türkischen Feldzuges 1912 und des Balkankriegs 1912-13, Hrsg: Central-Komitee der Deutschen Vereine vom Roten Kreuz, Springer Verlag, Berlin 1914. 
